\title{
1994 Annual Report on Waste Generation and Waste Minimization Progress as Required by DOE Order 5400.1, Hanford Site
}

\author{
Date Published \\ September 1995
}

\section{DISCLAIMER}

This report was prepared as an account of work sponsored by an agency of the United States Government. Neither the United States Government nor any agency thereof, nor any of their employees, makes any warranty, express or implied, or assumes any legal liability or responsibility for the accuracy, completeness, or usefulness of any information, apparatus, product, or process disclosed, or represents that its use would not infringe privately owned rights. Reference herein to any specific commercial product, process, or service by trade name, trademark, manufacturer, or otherwise does not necessarily constitute or imply its endorsement, recommendation, or favoring by the United States Government or any agency thereof. The views and opinions of authors expressed herein do not necessarily state or reflect those of the United States Government or any agency thereof.

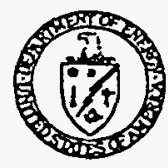

United States

Department of Energy

P.O. Box 550

Richland, Washington 99352 


\section{DISCLAIMER}

Portions of this document may be illegible in electronic image products. Images are produced from the best available original document. 


\section{Standard Data Report}

1994 Annual Report on Waste Generation and Waste Minimization Progress

as Required by DOE Order 5400.1

Hanford Site

state: WA

operations office: RI

Prepared for:

Department of Energy, Richland Operations Office

Prepared by:

Westinghouse Hanford Company

Report Date: 09/15/95 
Signature Page

T. K. Teynor, Director, Waste Programs Division, Richland Operations Office, DOE-RL

E. A. Dagan, Program Manager, Waste Minimization, DOE-RL

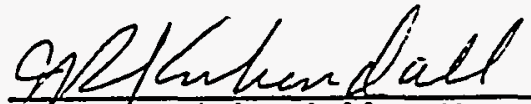

J. R. Kirkendall, Manager, cost Management Program office and pollution Prevention, Westinghouse Hanford Company

A.d Mpengy

D. S. Merry, LEAd, Pollution Prevention, Westinghouse Hanford Company

Point of Contact(DOE)

Name: Ellen B. Dagan

Dept: Richland

Phone: (509)376-3811

Fax: (509) 372-1926
Point of Contact (Contractor)

Name:Jill A. Engel

Dept: Westinghouse Hanford Company

Phone: (509) 376-8737

Fax: (509) 376-5560 
Table of Contents

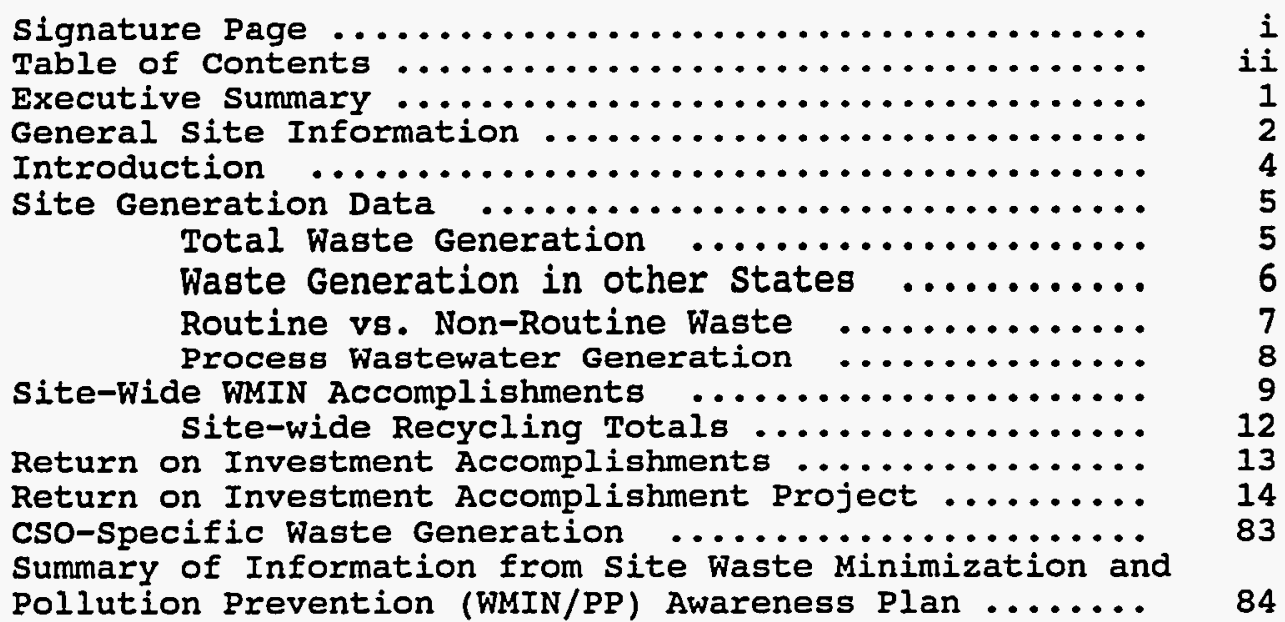




\section{Executive Summary}

While waste generation numbers are important, the true measure of success is waste minimized. Many Waste Minimization/Pollution Prevention (WMin/P2) successes at the Hanford site occur every day without formal recognition as pollution prevention, as they have become part of a culture of good management practices. As an example, the success of the excess and reuse program, both informal and formal, documents the WMin/P2 culture that exists in the pollution prevention representatives and employees at the facilities. A few of their other successful projects are:

- T-plant helps facilities reuse equipment by offering decontamination services for items such as gas cylinders, trucks, and railcars, thus saving disposal and equipment replacement costs. During 1994, T-Plant helped avoid 96.1 cubic meters of low level waste and saved $\$ 386,000$.

- At 222-s Labs, a chemist found a substitute for the industrial strength tape that was used to hold glass vials in vortex shakers. To eliminate use and disposal of the tape, an adjustable velcro strap was attached to the vortex shakers, saving 0.6 cubic meters of mixed waste and $\$ 46,000$ annually.

- Custodial Services reviewed its use of 168 hazardous cleaning products, and, through a variety of measures, replaced them with 38 safer substitutes, one for each task. This saves $3,400 \mathrm{kilograms}$ of hazardous waste, 70.5 cubic meters of sanitary waste, for a total cost savings of $\$ 160,800$ per year.

- Scrap steel contaminated with low level radioactivity from the interim stabilization of $107-\mathrm{K}$ and $107-\mathrm{C}$ was decontaminated and sold to a vendor for recycling. Approximately 448 cubic meters of low level waste was avoided, and $\$ 1,066,000$ was avoided in disposal costs and received in revenue.

Several site-wide programs have also reduced large amounts of waste, including the following programs:

- The Pollution Prevention Opportunity Assessment(P2OA) program at the Hanford Site was launched during 1994, including a training class, a guidance document, technical assistance, and goals.

- Control over hazardous materials purchased was achieved by reviewing all purchase requisitions of a chemical nature. This review process avoided over 20 cubic meters of hazardous waste and $\$ 15,000$ in disposal costs.

- The office Supply Reuse Program was established to redeploy unused or unwanted office supply items. In 1994, 12,467 items were redeployed through this program, saving over $\$ 50,000$ in new material costs alone.

In 1994, pollution prevention activities reduced approximately 274,000 kilograms of hazardous waste, 2,100 cubic meters of radioactive and mixed waste, $14,500,000$ kilograms of sanitary waste, and 215,000 cubic meters of liquid waste and waste water. Pollution Prevention activities also saved almost $\$ 4.2$ million in disposal, product, and labor costs. Overall waste generation increased in 1994 due to increased work and activity typical for a site with an environmental restoration mission. However, without any Waste Minimization/Pollution Prevention activities, solid radioactive waste generation at Hanford would have been 258 higher, solid hazardous waste generation would have been $30 \%$ higher, and solid sanitary waste generation would have been $60 \%$ higher, a trend of increasing waste reduction that will continue at the Hanford site. 


\section{General Site Information}

\section{General Site Mission}

The primary mission at the Hanford site is to clean up the site, provide scientific and technological excellence to meet global needs, and to partner in the economic diversification of the region.

The Hanford Site was established in 1943 to produce plutonium and for the next 40 years the site worked under a defense production mission. From the late 1980 s to the present, the Hanford Site stopped production and now has a complete environmental restoration mission. Its focus is to decommission the reactors and Site facilities, as well as clean up the 1,450 square kilometers of land.

This is an immense and challenging undertaking, which includes content characterization and decommissioning of 149 single shell storage tanks, treating 28 double shell tanks, safely disposing spent nuclear fuel (808 of DOE's inventory) stored on site, removing over 500 buildings, as well as dealing with significant solid waste, ground water, and land restoration issues.

In accomplishing the Hanford site mission of cleanup, the objective will be to do so in a manner that will eliminate potential risks to the public, and serve as the DOE model in environmental restoration. Pollution Prevention is a key to the success of this clean up mission.

Other missions at the Hanford site include energy research and development, as well as waste management and disposal activities. The Hanford Site will continue to be a national resource for scientific, technical, and engineering capabilities and innovation with a special focus on environmental cleanup processes and technologies.

\section{Mailing Address}

P.O. Box 550

MSIN S7-55

Richland, WA 99352

Lead cso

Additional csos

\begin{tabular}{|l|l|l|l|l|l|l|l|l|l|l|l|l|l|}
\hline $\mathrm{EM}$ \\
\hline $\mathrm{AD}$ & $\mathrm{CR}$ & $\mathrm{DP}$ & $\mathrm{EE}$ & $\mathrm{EM}$ & $\mathrm{ER}$ & $\mathrm{ET}$ & $\mathrm{FE}$ & $\mathrm{HR}$ & $\mathrm{NE}$ & $\mathrm{NN}$ & $\mathrm{PM}$ & $\mathrm{RW}$ \\
\hline & & & & & & & & & & & & \\
\hline
\end{tabular}

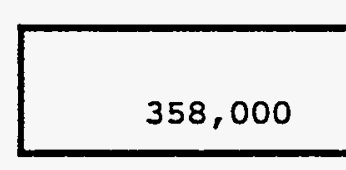

DOE

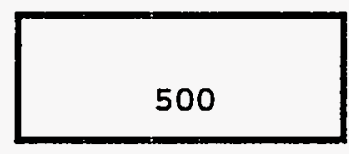

Contractor

13300 
Data contained in this report represents waste generation in the following states (8):

WA 


\section{Introduction}

\section{GENERAL INTRODUCTION}

While waste generation numbers are important, the key to this report is the waste minimization successes, both site-wide and facility (cso) specific. Only a selection of the many WMin/P2 successes at Hanford are reported here. Many occur every day without formal recognition as $P 2$, as they have instead become part of a culture of good management practices. The success of the excess and reuse program, both informal and formal, documents this whin/P2 culture. The Hanford site is particularly proud of the many small activities that occur at the over 30 waste generating facilities, since these successes are brought about by the pollution prevention representatives and employees at the facilities. Additionally, several site-wide programs have reduced large amounts of waste, as well as assisted the facilities in their activities as requested.

\section{INTRODUCTION TO SITE GENERATION DATA}

Since Hanford only has one cso, no difficulties were encountered tracking to a cso level. The solid containerized waste data was available using a site-wide tracking system, and the bulk liquid numbers were available with a little more difficulty. Since the waste generation information comes from a single site source, the information here is consistent with other reports, given adjustments for different parameters requested in each report. The inventory values for radioactive waste may reflect different definitions of waste types (especially high level and mixed waste), in order to be consistent with the Integrated Database Report.

One small portion of waste was not tracked or reported--sanitary landfill waste that goes to the City of Richland landfill, as opposed to the site landfill. This waste is office waste from leased downtown buildings. The actual amounts of this waste are not tracked, although the total numbers are within +/$20 \%$ of the reported value. Reporting only the site landfill numbers was also done to keep the number consistent with what was reported the last three years. This may change next reporting year as the site landfill is slated for closure December 1995 and all site waste will go to the City of Richland landfill.

Measurement points as listed in the handbook were followed and are consistent with state reported data.

The separation of Routine and Non-Routine waste was completed and automated through the addition of a Routine field in the Hanford solid waste tracking system. Non-Routine waste includes backlog ("legacy") waste reprocessed and major ER/D\&D activities. Primary and secondary waste totals were not tracked and cannot be tracked easily at Hanford. No plans are made to distinguish between these in the near future.

Waste increases resulted from increased work and activity typical for a site with an environmental restoration mission. The only significant increase in routine waste was for TRU-Mixed waste. This was caused by an increase in transition activities at the Plutonium Finishing plant. Note that without any Pollution Prevention/Waste Minimization activities, solid radioactive waste generation at Hanford would have been $25 \%$ higher, solid hazardous waste generation would have been $30 \%$ higher, and solid sanitary waste generation would have been 60 \% higher.

In "ROI Accomplishments" (Section VI), an assumption of a 10 year useful life was made if the project life was not known and the activity was on-going. If the accomplishment was a one-time event, the useful project life was reported to be 1 .

In the "Site-wide quantitative Goals for Newly Generated Wastes" table, the reductions are based on percentages of Routine waste generation from the baseline year of 1993, not the Total Baseline values brought in by the program.

Finally, please note that the "Hanford site," as defined for this report, includes Hanford's primary contractors but not the national laboratory on-site. Pacific Northwest Laboratory is reported separately and is not included in this document. 
IV. Site Generation Data

Table 1.0 Total Waste Generated in 1994

as Packaged for $T / S / D$

(does not include process wastewater)

\begin{tabular}{|c|c|c|c|c|}
\hline Waste Type & Liquid & solid & Total & $\begin{array}{l}\text { Inventory* } \\
\text { Waste } \\
\text { (as of 12/93) }\end{array}$ \\
\hline High Level Waste & $0 \mathrm{~m} 3$ & $0 \mathrm{~m} 3$ & $0 \mathrm{~m} 3$ & $262000 \mathrm{~m} 3$ \\
\hline Transuranic Waste (TRU) & $0 \mathrm{~m} 3$ & $195 \mathrm{~m} 3$ & $195 \mathrm{~m} 3$ & $15700 \mathrm{~m} 3$ \\
\hline Mixed-TRU & $0 \mathrm{~m} 3$ & $102 \mathrm{~m} 3$ & $102 \mathrm{~m} 3$ & $175 \mathrm{~m} 3$ \\
\hline Low-Level Waste (ILW) & $0 \mathrm{~m} 3$ & $4120 \mathrm{~m} 3$ & $4120 \mathrm{~m} 3$ & $602000 \mathrm{~m} 3$ \\
\hline Mixed-IIW & $2500 \mathrm{~m} 3$ & $2310 \mathrm{~m} 3$ & $4810 \mathrm{~m} 3$ & $3870 \mathrm{~m} 3$ \\
\hline RCRA Regulated & & $356 \mathrm{mt}$ & $356 \mathrm{mt}$ & $132 \mathrm{mt}$ \\
\hline State Regulated & & $186 \mathrm{mt}$ & $186 \mathrm{mt}$ & $21.7 \mathrm{mt}$ \\
\hline TSCA Regulated & & $85.5 \mathrm{mt}$ & $85.5 \mathrm{mt}$ & $23.2 \mathrm{mt}$ \\
\hline Mixed-TSCA & & $0.590 \mathrm{mt}$ & $0.590 \mathrm{mt}$ & $87.4 \mathrm{mt}$ \\
\hline Sanitary & & $9160 \mathrm{mt}$ & $9160 \mathrm{mt}$ & \\
\hline
\end{tabular}

* Total waste generated at the site during calendar year 1994, which is a sum of all wastes generated, regardless

of source or activity; also provided for reference is the total amount of waste in inventory at the site, as of $12 / 93$. 
IV. Site Generation Data (cont.)

Table 1.1 Amount of Waste Generated in Other States by this Site's Operations or Activities

You have indicated that you are reporting waste for only 1 state. Therefore, this page is intentionally blank. 
IV. Site Generation Data (cont.)

Table 2.0 Routine * vs. Non-Routine ** Waste

\begin{tabular}{|c|c|c|c|c|}
\hline Waste Type & & Routine & Non-Routine & Total \\
\hline Bigh Level Waste & $\begin{array}{l}\text { (I) } \\
\text { (S) }\end{array}$ & $\begin{array}{ll}0 & \mathrm{~m} 3 \\
0 & \mathrm{~m} 3\end{array}$ & $\begin{array}{ll}0 & \mathrm{~m} 3 \\
0 & \mathrm{~m} 3\end{array}$ & $\begin{array}{l}0 \mathrm{~m} 3 \\
0 \mathrm{~m} 3\end{array}$ \\
\hline Transuranic Waste (TRU) & $\begin{array}{l}\text { (I) } \\
\text { (S) }\end{array}$ & $\begin{array}{rl}0 & \mathrm{~m} 3 \\
195 & \mathrm{~m} 3\end{array}$ & $\begin{array}{ll}0 & \mathrm{~m} 3 \\
0 & \mathrm{~m} 3\end{array}$ & $\begin{array}{r}0 \mathrm{~m} 3 \\
195 \mathrm{~m} 3\end{array}$ \\
\hline Mixed-TRU & $\begin{array}{l}\text { (L) } \\
\text { (S) }\end{array}$ & $\begin{array}{r}0 \mathrm{~m} 3 \\
102 \mathrm{~m} 3\end{array}$ & $\begin{array}{ll}0 & \mathrm{~m} 3 \\
0 & \mathrm{~m} 3\end{array}$ & $\begin{array}{r}0 \mathrm{~m} 3 \\
102 \mathrm{~m} 3\end{array}$ \\
\hline Low-Level Waste (ILW) & $\begin{array}{l}\text { (L) } \\
\text { (S) }\end{array}$ & $\begin{array}{rl}0 & \mathrm{~m} 3 \\
3900 \mathrm{~m} 3\end{array}$ & $\begin{array}{r}0 \mathrm{~m} 3 \\
218 \mathrm{~m} 3\end{array}$ & $\begin{array}{r}0 \mathrm{~m} 3 \\
4120 \mathrm{~m} 3\end{array}$ \\
\hline Mixed-ILW & $\begin{array}{l}\text { (L) } \\
\text { (S) }\end{array}$ & $\begin{aligned} 2500 \mathrm{~m} 3 \\
570 \mathrm{~m} 3\end{aligned}$ & $\begin{array}{rl}0 & \mathrm{~m} 3 \\
1740 & \mathrm{~m} 3\end{array}$ & $\begin{array}{l}2500 \mathrm{~m} 3 \\
2310 \mathrm{m3}\end{array}$ \\
\hline RCRA Regulated & & $70.9 \mathrm{mt}$ & $285 \mathrm{mt}$ & $356 \mathrm{mt}$ \\
\hline State Regulated & & $138 \mathrm{mt}$ & $47.6 \mathrm{mt}$ & $186 \mathrm{mt}$ \\
\hline TSCA Regulated & & $0 \mathrm{mt}$ & $85.5 \mathrm{mt}$ & $85.5 \mathrm{mt}$ \\
\hline Mixed-MSCA & & 0 mt & $0.590 \mathrm{mt}$ & $0.590 \mathrm{mt}$ \\
\hline
\end{tabular}

Total waste generated at the site during calendar year 1994, which is a sum of all wastes generated regardless of source or activity

* Routine waste is defined as waste produced from any type of production operation, analytical and/or R\&D laboratory operations; T/S/D operations, "work for others", or any other periodic and recurring work that is considered on-going in nature.

* Non-Routine waste is defined as one-time operations waste: Wastes produced from environmental restoration program activities, including primary and secondary wastes associated with retrieval and remediation operations;

"legacy wastes"; and D\&D/Transition operations. 
IV. Site Generation Data (cont.)

Table 2.1 Process Wastewater* Generation

\begin{tabular}{|c|c|}
\hline Waste Type & Volume (1000 Liters) $=1 \mathrm{~m} 3$ \\
\hline High Level Waste & $0 \mathrm{~m} 3$ \\
\hline Transuranic Waste (TRU) & $0 \mathrm{~m} 3$ \\
\hline Mixed-TRU & $0 \mathrm{~m} 3$ \\
\hline Low-Level Waste (LLW) & $0 \mathrm{~m} 3$ \\
\hline Mixed-ILW & $0 \mathrm{~m} 3$ \\
\hline RCRA Regulated & $0 \mathrm{~m} 3$ \\
\hline State Regulated & $0 \mathrm{~m} 3$ \\
\hline TSCA Regulated & $0 \mathrm{~m} 3$ \\
\hline Mixed-TSCA & $0 \mathrm{~m} 3$ \\
\hline Sanitary & $29000 \mathrm{~m} 3$ \\
\hline
\end{tabular}

Total waste generated at the site during calendar year 1994, which is a sum of all wastes generated regardless of source or activity

* Process Wastewater is defined as any water produced during manufacturing or processing operations which comes into direct contact with or results from the production or use of any raw material, intermediate product, finished product, by-product, or waste product. This determination is independent of the level and/or nature of the contaminants. 


\section{v. Site-Wide WMIN Accomplishments}

Site-wide Pollution Prevention activities were accomplished by all of the main contractors at Hanford in CY 1994--Westinghouse Hanford Company (WHC), ICF Kaiser Hanford (ICF KH), Environmental Restoration Contractor Team (ERC), Boeing Computer Services Richland (BCSR), and Hanford Environmental Health Foundation (HEHF). Pacific Northwest Laboratory (PNL) reports separately, thus is not included here. The following site-wide activities were completed individually or jointly by the contractors.

\section{POLLUTION PREVENTION OPPORTUNITY ASSESSMENT PROGRAM}

The Pollution Prevention Opportunity Assessment (PPOA) program at the Hanford site began and proceeded to be a success during 1994. PPOAs have helped significantly to identify ways to reduce waste. The program began in March when the pollution prevention group began researching PPOAs with the stated goal to implement a Hanford PPOA program by December 31, 1994. This goal was met through several stages. First, a "benchmarking" study of Hanford facilities, other sites (especially Kansas City Plant), DOE guidance documents, and regulations was completed in April (WHC-SA-2439-FP). From this study PPOAs were introduced to Hanford facilities through a pilot training session held in May 1994. Second and third sessions of pilot training were held during the summer. The training was finalized in August 1994 (WHC-MR-0469). A facility guidance document was completed in October 1994 (WHC-MR-0472) and technical assistance was expanded to include PPOAs.

From this program, 6 PPOAs were completed in 1994, several of them funded by DOE-HQ funds specifically to conduct PPOAs. In 1995, opportunities from these PPOAs and others will be implemented. Additionally, facilities will be required to set goals for completing a certain number of PPOAs during 1995 to encourage them to conduct assessments.

\section{OFFICE SUPPLY REUSE PROGRAM}

The Office Supply Reuse Program which began in February 1994, was established as a means to redeploy unused or unwanted office supply type items to individuals who could use them. By reutilizing items through this program, savings are realized by saving storage space that the unneeded items take up, landfill space if those items are thrown away, and the cost of sending items through the excess process which includes paperwork processing and handling of the material. In addition to these savings, the person acquiring an item has avoided the cost of purchasing the item new, as well as the cost of processing a purchase requisition or processing a store order through the Central stores Inventory.

In 1994, 1,085 line items, 12,467 individual items in all, were redeployed through this program. This resulted in savings of over $\$ 50,000$ in new material costs alone.

\section{SCRAP WOOD RECYCLING}

A wood laydown yard for collecting scrap wood for recycling was opened in November 1994. Scrap pallets and other clean scrap wood will be collected at the yard for routine pick up by a local vendor. This vendor will also to rebuild good, usable pallets and return them to the Central stores Warehouse at a substantially lower price than new pallets. All other scrap wood items unavailable for these programs will be chipped at the Richland landfill and used for various recycling applications.

EXCESS CHEMICALS, METALS \& EQUIPMENT

The concept of reusing, excessing and recycling equipment, scrap metals, chemicals, and other materials has been integrated into the facilities at Hanford with significant success. All the facilities at Hanford reported multiple reuse and excess successes, from batteries to lead shielding to instrumentation. Although some exchanges happened through the Recycling or Pollution Prevention groups, many occurred informally, which is evidence of a pollution prevention 
culture among facility personnel.

A more formal program managed by the Recycle office helps facilities excess and recycle hazardous chemicals no longer needed. Once a declaration of excess form is completed by the facility generator, the Recycling office staff attempts to find another on-site user for the unwanted chemicals. If no on-site user can be found, auctions are held a few times a year for public sale to off-site buyers. In CY 1994, 56,370 liters of liquid chemicals and 57,000 kilograms of solid chemicals were excessed, preventing them from being disposed of as hazardous waste.

\section{AUTO EARTH DAY}

Recycled and environmentally sound automotive products were featured at Auto Earth Day. Auto Earth Day was a team effort including the Department of Energy, Westinghouse Hanford Company, Battelle Pacific Northwest Laboratory, Benton County, Franklin County, City of Richland, and the Clean Washington Center. This one-day event was an opportunity to educate the general public and to assist local small automotive businesses in identifying pollution prevention opportunities for their own shops.

Sixteen vendors from Washington, Idaho and Oregon came to the Tri-Cities for the october first event. They displayed a variety of recycled products and waste reducing equipment. Through presentations, each shared a particular pollution prevention solution to the wastes associated with automotive shops and consumer use.

Among the products was an oil filter crusher, a waterless car wash product, a battery with no free flowing acid, and a parts washer which utilized a reusable citrus-based solvent. In addition, five environmentally friendly vehicles were on display, including a solar powered car, a hybrid-electric car, electric scooters, and a 1994 Mazda made from $85 \%$ recycled materials.

\section{POLIUTION PREVENTION TRAINING}

An introductory workshop on pollution prevention was developed and tailored by WHC for the ERC Team D\&D/ER employees. The workshop objectives were to identify terms and concepts relative to pollution prevention, and recognize pollution prevention opportunities in the workplace. The objectives are met by defining pollution prevention, including the EPA hierarchy of pollution prevention, the pollution prevention drivers, sharing the benefits of pollution prevention, and giving techniques and examples of pollution prevention. The course is 1 hour in length and includes a module on examples of pollution prevention accomplishments and opportunities in the ERC Team projects.

In 1994, approximately 100 employees, including management, plant operators, craft personnel, and engineers were trained. About 200 additional employees will be trained in early 1995.

\section{HAZARDOUS MATERIAL REDUCTION INITIATIVE}

Requisitions for hazardous chemicals at Hanford are filled through Central Stores. Effective control over the toxicity and amount of hazardous materials purchased is achieved by reviewing all purchase requisitions of a chemical nature. These requisitions are examined to ascertain if the product is available elsewhere on Site as surplus, if a less hazardous substitute is available, or if less of the product will suffice. This review process avoids an estimated 20 cubic meters of hazardous waste and $\$ 15,000$ in disposal costs annually.

The pollution prevention group also communicates with buyers and end users to identify and test non-hazardous or less hazardous products that can do the same job, as well as improve worker health and safety, minimize waste, and reduce disposal costs.

\section{RECOGNITION}

The Pollution Prevention Accomplishments Book, featuring 33 pollution prevention success stories, was developed including text and a photo for each entry. A special pollution Prevention Celebration was given in honor of the employees who contributed successes listed in the Fiscal Year 1994 Pollution 
Prevention Accomplishments Book. Senior Managers from each organization presented Accomplishments Books to those employees.

\section{ENERGY CONSERVATION}

The Hanford Site acquires low cost electrical power making energy conservation projects difficult to cost-effectively justify. The Energy Management group actively pursued conservation opportunities available through design-side management incentive programs offered locally by the City of Richland and the Bonneville Power Administration. Some of the projects active in 1994 included transformer, lighting, motor, and compressor replacements with energy efficient versions.

The projects in 1994 received $\$ 43,156$ in rebates from the Bonneville Power Administration and the City of Richland and were expected to save 14.5 million kilowatt-hours. 


\section{v. Site-Wide WMIN Accomplishments (cont.)}

Table 3.0 Site-Wide Recycling Activities

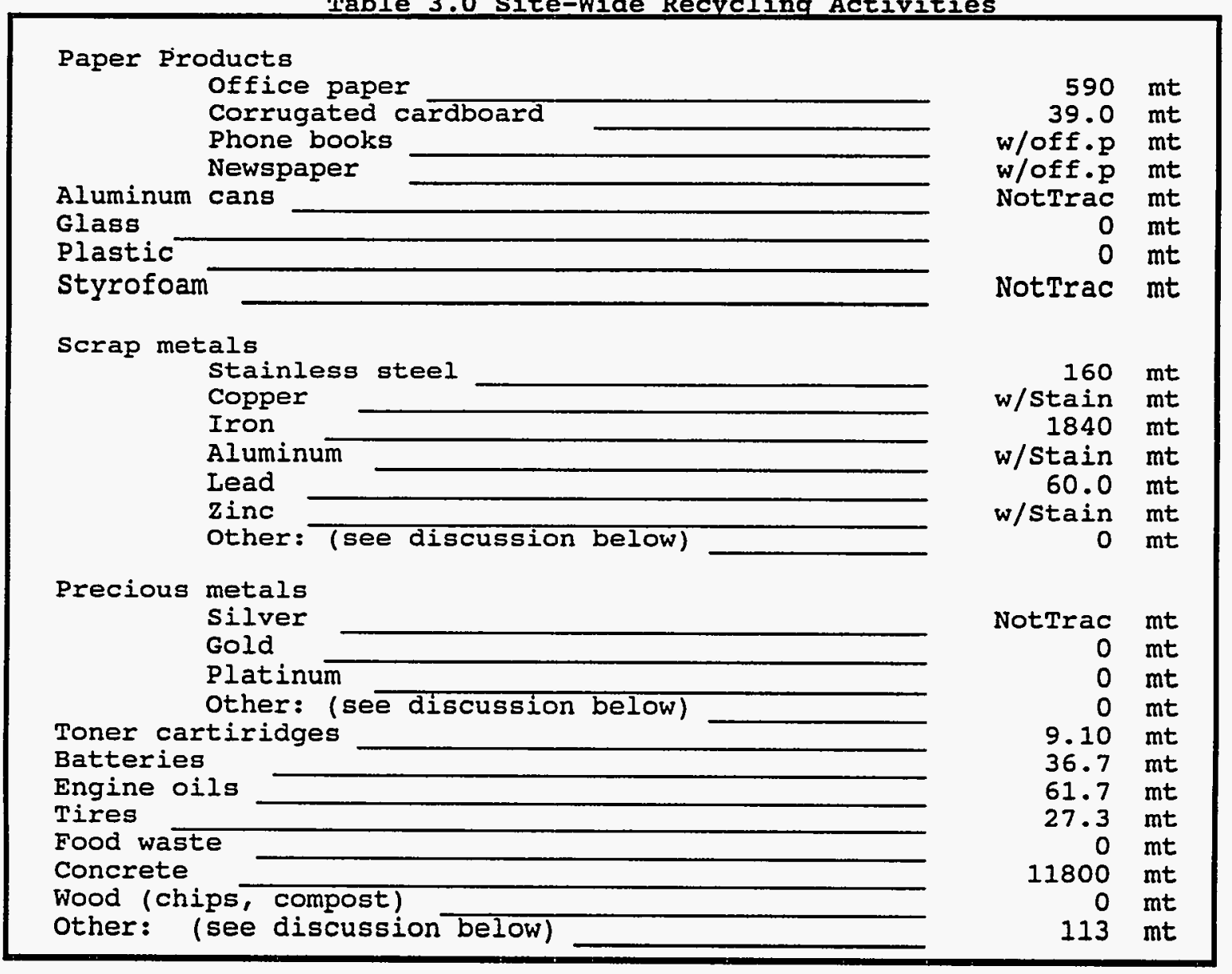

The stainless steel category is a non-ferrous metal total (160 mt). The iron category is a ferrous metal total (1,840 mt).

The 'Other' category is chemical exchange (reuse), both on-site and off-site. The value comes from 56,370 liters of liquid chemicals (assumed specific gravity $=1.0$ ) and $57 \mathrm{mt}$ of solid chemicals, reused or sold for reuse. 


\section{Return on Investments Accomplishments}

Waste/Pollutant Quantity Reduction:

Prevented Waste: (Type and amount)

Air Emisgion-

Amount/Year:

Implementing CSO: EM

Activity Identification Method: T05

$$
0 \mathrm{mt} / 1994
$$

Serial Number: 22

source reduction activity: $\mathbf{5} 2$ OR recycling activity:

Status:

Comments:

included above. 
vI. Return on Investment Accomplishment Project

Project Title: WHC, 300 Area LEF, Reduction of Automotive Pollutants

Serial Number: 22

Operations office/Site: RL/Hanford site

Implementing CSO: EM

Site Contact: Ellen B. Dagan

(509) 376-3811/(509) 372-1926

Phone/Fax:

Project Start Date $=/ /$

\section{Project Description:}

The 300 Area Liquid Effluent Facility (LEF) purchased 3 bicycles in 1994 for transportation in the 300 Area in lieu of automobiles. This minimized the use of personal and government-owned vehicles for short duration trips which cause the most pollution because the vehicle's engine does not reach an efficient operating temperature. The use of bicycles has reduced vehicle usage by an undetermined number of miles, while not resulting in a significant increase in the amount of time to reach destinations in the congested 300 Area.

Project Duration (months):

Useful Project Life (Years):

Performance Indicators: $\frac{R O I=[B-A]-\{[C+E] / L\} \times 100}{[C+E]}=0$

O\&M Annual Recurring Costs

(i.e. Total Annual Operating Costs) (Dollars in Thousands)

Annual Costs, Before $=$

Annual Costs, After =

Net Annual Savings $=0$
Project Funding Requirements: .

(i.e. One-Time Implementation costs) (Dollars in Thousands)

(B) Capital Investment $=$

(A) Installation Operating Expense $=$

Total Project Funds $=(C)+(E)=0$ 
VI. Return on Investments Accomplishments

Waste/Pollutant Quantity Reduction:

Prevented Waste: (Type and amount)

Air Emission-

Implementing CSO: EM

Activity Identification Method: T05

Serial Number: 35
Amount/Year:

$$
0.100 \mathrm{~m} 3 / 1994
$$

source reduction activity:

OR recycling activity: $R 99$

Status:

Comments:

included above. 
VI. Return on Investment Accomplishment Project

Project Title: ICF KH, 1171, Freon Recycling

Serial Number: 35

Operations office/site: RL/Hanford site

Implementing CSO: EM

Site Contact: Ellen B. Dagan

(509) 376-3811/(509) 372-1926

Phone/Fax:

Project start Date $=/ /$

Project Description:

Freon, $R-12, R-22$, and $R-134$ a formulations, are recycled on site by licensed technicians at Fleet Maintenance. In a normal maintenance scenario, the coolant system from the vehicle is evacuated, the necessary changes are made, and the coolant system is recharged with the same freon. If the coolant system is being removed from service, the freon is evacuated and stored for later use. Freon containers are returned to the vendor for reuse or recycling.

Project Duration (months):

Useful Project Iife (Years): 10

Performance Indicators: $\frac{R O I=[B-A]-\{[C+E] / L\} \times 100}{[C+E]}=0$

O\&M Annual Recurring Costs

(i.e. Total Annual Operating Costs) (Dollars in Thousands)

Annual Costs, Before $=2.150$

Annual Costs, After $=0$

Net Annual Savings $=2.150000$
Project Funding Requirements:

(i.e. One-Time Implementation Costs) (Dollars in Thousands)

(B) Capital Investment =

(A) Installation Operating Expense $=$ 
VI. Return on Investments Accomplishments

Waste/Pollutant Quantity Reduction:

Prevented Waste: (Type and amount)

Amount/Year:

Low-Level Waste (LLW)-Solid

$0.500 \mathrm{~m} 3 / 1994$

Implementing CSO: EM

Activity Identification Method: T05

source reduction activity:

OR recycling activity:

Serial Number: 14

\section{Status:}

This compaction is an on-going activity to reduce waste volume.

Comments:

Included above.

This is treatment (volume reduction). 


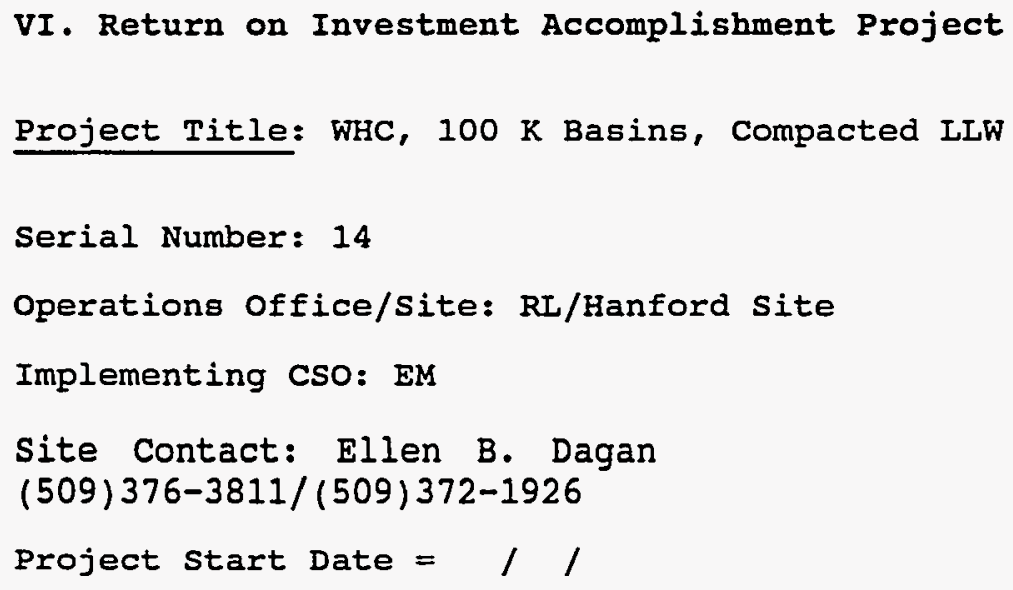

\section{Project Description:}

Assorted waste from K-Basins, generated during normal operations, was compacted to a ratio of $5: 1$ to reduce volume and disposal costs.

Project Duration (months):

Useful Project Life (Years): 10

Performance Indicators: $\frac{\text { ROI }=[B-A]-\{[C+E] / L\} \times 100}{[C+E]}=969.04$

O\&M Annual Recurring Costs

(i.e. Total Annual Operating Costs) (Dollars in Thousands)

Annual Costs, Before $=48.952$

Annual Costs, After =

Net Annual Savings
Project Funding Requirements:

(i.e. One-Time Implementation costs) (Dollars in Thousands)

(B) Capital Investment $=0$

(A)

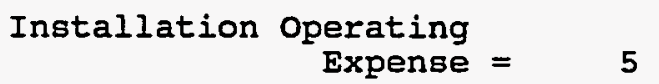


VI. Return on Investments Accomplishments

Waste/Pollutant Quantity Reduction:

Prevented Waste: (Type and amount)

Amount/Year:

Low-Level Waste (LLW)-Solid

$24.4 \mathrm{~m} 3 / 1994$

Implementing CSO: EM

Activity Identification Method: T05

source reduction activity:

OR recycling activity:

Serial Number: 2

Status:

This activity is on-going at B-Plant.

Comments:

included above.

This project involves both segregation (source reduction) and treatment. 
VI. Return on Investment Accomplishment Project

Project Title: WHC, B-Plant, Compactible ILW

Serial Number: 2

Operations office/Site: RL/Hanford Site

Implementing CSO: EM

Site Contact: Ellen B. Dagan

(509) 376-3811/(509) 372-1926

Phone/Fax:

Project start Date $=/ /$

Project Description:

Low level waste at B-Plant complex is segregated into compactible and non-compactible portions. The compactible LLW is sent to a compaction facility. This minimizes disposal volume and saves space at the burial grounds. Waste consists of low level paper, rubber, cloth, and such, from routine operations.

Project Duration (months):

Useful Project Life (Years): 10

Performance Indicators: $\frac{\operatorname{ROI}=[\mathrm{B}-\mathrm{A}]-\{[\mathrm{C}+\mathrm{E}] / \mathrm{L}\} \times 100}{[\mathrm{C}+\mathrm{E}]}=850.00$

O\&M Annual Recurring costs

(i.e. Total Annual Operating costs) (Dollars in Thousands)

Annual Costs, Before $=43$

Annual Costs, After $=0$

Net Annual Savings $=43$
Project Funding Requirements:

(i.e. One-Time Implementation costs) (Dollars in Thousands)

(B) Capital Investment $=0$

(C)

(A) Installation Operating Expense $=$ 5

Total Project Funds $=(C)+(E)=5$ 


\section{Return on Investments Accomplishments}

Waste/Pollutant Quantity Reduction:

Prevented Waste: (Type and amount)

Low-Level Waste (ILW)-Solid

Implementing CSO: EM

Activity Identification Method: T05

Serial Number: 20
Amount/Year:

$107 \mathrm{~m} 3 / 1994$ source reduction activity:

OR recycling activity:

\section{status:}

This is an on-going activity.

\section{Comments:}

included above.

This activity is treatment. 
VI. Return on Investment Accomplishment Project

Project Title: WHC, 222 S Labs, Compaction of LLW

Serial Number: 20

Operations office/site: RL/Hanford site

Implementing CSO: EM

Site Contact: Ellen B. Dagan

(509) 376-3811/(509)372-1926

Phone/Fax:

Project Start Date $=/ /$

Project Description:

Solid low-level waste is generated inside the laboratory and consists of compactible waste such as gloves, paper, soft plastics, and cloth. This material is being segregated and sent to the compactor facility at $100 \mathrm{~N}$ in returnable containers. This material is then compacted in 55-gallon drums and shipped for disposal. A volume reduction ratio of 5.7:1 was achieved in 1994 .

Project Duration (months):

Useful Project Life (Years): 10

Performance Indicators: $\frac{\operatorname{ROI}=[B-A]-\{[C+E] / L\} \times 100}{[C+E]}=0$

O\&M Annual Recurring Costs

(i.e. Total Annual Operating costs) (Dollars in Thousands)

Annual Costs, Before $=189$

Annual Costs, After =

Net Annual Savings

$=189$
Project Funding Requirements:

(i.e. One-Time Implementation Costs) (Dollars in Thousands)

(B) Capital Investment =

(A) Installation Operating

$$
\text { Expense }=
$$

Total Project Funds $=(C)+(E)=0$ 
VI. Return on Investments Accomplishments

Waste/Pollutant quantity Reduction:

Prevented Waste: (Type and amount)

Low-Level Waste (LLW)-Solid

Implementing CSO: EM

Activity Identification Method: T11

Serial Number: 23
Amount/Year:

$96.1 \mathrm{~m} 3 / 1994$ source reduction activity:
OR recycling activity: R99

\section{Status:}

Decontamination services is the mission of $\mathrm{T}-\mathrm{Plant}$. The material and equipment reported in this success is part of their workscope and represents a success for all the facilities who send items to T-Plant. This activity is on-going.

Comments:

included above.

This project involves treatment (decontamination) to allow reuse and recycle. 
VI. Return on Investment Accomplishment Project

Project Title: WHC, T-Plant, Decontamination of Equipment

Serial Number: 23

Operations office/site: RL/Hanford Site

Implementing CSO: EM

Site Contact: Ellen B. Dagan

Phone/Fax:

(509) 376-3811/(509) 372-1926

Project start Date $=/ /$

\section{Project Description:}

T-Plant recycled various types of equipment by decontamination in the 2706-T facility. The types of equipment included gas cylinders, trucks, and railcars. Decontaminating avoids the cost of disposal and replacement of the equipment.

Project Duration (months):

Useful Project Life (Years): 10

$\frac{\text { Performance Indicators: }}{\operatorname{ROI}=[B-A]-\{[C+E] / L\} \times 100}=0$

O\&M Annual Recurring Costs

(i.e. Total Annual Operating Costs) (Dollars in Thousands)

Annual Costs, Before $=386.77$

Annual Costs, After =

Net Annual Savings $=386.7700$
Project Funding Requirements:

(i.e. One-Time Implementation Costs) (Dollars in Thousands)

(B) Capital Investment =

(A) Installation Operating

Expense $=$

Total Project Funds $=(C)+(E)=0$ 
VI. Return on Investments Accomplishments

Waste/Pollutant Quantity Reduction:

Prevented Waste: (Type and amount)

Low-Level Waste (LLW)-Solid

Implementing CSO: EM

Activity Identification Method: T05 ,

Serial Number: 29
Amount/Year:

$28.4 \mathrm{~m} 3 / 1994$ source reduction activity:

OR recycling activity: $R 99$

\section{Status:}

This project was implemented in 1994 and is on-going.

Comments:

included above. 
VI. Return on Investment Accomplishment Project

Project Title: WHC, Rad Control, Recycling Rad Warning Signs

Serial Number: 29

Operations office/Site: RL/Hanford Site

Implementing cso: EM

Site Contact: Ellen B. Dagan

(509) 376-3811/(509) 372-1926

Phone/Fax:

Project start Date $=/ /$

\section{Project Description:}

Changing regulations and rad zone changes frequently require radiological warning signs to be redesigned or removed, requiring a complete change-out of all radiological warning signs on-site. The radiological symbol (trifoil) on the signs requires the entire sign to be disposed of as LLW. A vendor was contacted in Redmond, Washington, who was willing the accept the signs. The vendor completely destroys the trifoil by shredding the signs, and recycles the metal into underground piping.

Project Duration (months):

Useful Project Life (Years): 10

Performance Indicators: $\frac{\operatorname{ROI}=[B-A]-\{[C+E] / L\} \times 100}{[C+E]}=0$

O\&M Annual Recurring Costs

(i.e. Total Annual Operating costs) (Dollars in Thousands)

Annual Costs, Before $=150$

Annual Costs, After $=0$

Net Annual Savings $=150$
Project Funding Requirements:

(i.e. One-Time Implementation Costs) (Dollars in Thousands)

(B) Capital Investment =

(A) Installation Operating Expense $=$

Total Project Funds $=(C)+(E)=0$ 
vI. Return on Investments Accomplishments

Waste/Pollutant Quantity Reduction:

Prevented Waste: (Type and amount)

Amount/Year:

Low-Level Waste (LLW)-Solid

$448 \mathrm{~m} 3 / 1994$

Implementing CSO: EM

Activity Identification Method: T05

source reduction activity:

OR recycling activity: $R 30$

Serial Number: 3

\section{Status:}

Project was completed during the interim stabilization of $107-\mathrm{K}$ and 107-C, two on-site buildings. It will continue to be applied to similar D\&D efforts.

Comments:

included above. 


\section{Return on Investment Accomplishment Project \\ Project Title: ERC, 107-K \& 107-C, Interim Stabilization Recycling}

Serial Number: 3

Operations office/Site: RI/Hanford site

Implementing CSO: EM

Site Contact: Ellen B. Dagan

(509) 376-3811/(509) 372-1926

Phone/Fax:

Project start Date $=/ /$

\section{Project Description:}

Low level contaminated steel from the Interim Stabilization projects on 107-K and 107-C was decontaminated and sold to a scrap vendor for recycling.

Project Duration (months):

Useful Project Life (Yearg): 1

Performance Indicators: $\frac{\operatorname{ROI}=[B-A]-\{[C+E] / L\} \times 100}{[C+E]}=0$

O\&M Annual Recurring Costs

(i.e. Total Annual Operating Costs) (Dollars in Thousands)

Annual Costs, Before $=1066$

Annual Costs, After $=0$

Net Annual Savings $=1066$
Project Funding Requirements:

(i.e. One-Time Implementation Costs) (Dollars in Thousands)

(B) Capital Investment =

(A) Installation Operating

Expense $=$

Total Project Funds $=(C)+(E)=0$ 
VI. Return on Investments Accomplishments

Waste/Pollutant Quantity Reduction:

Prevented Waste: (Type and amount)

Amount/Year:

Low-Level Waste (LLW)-Solid

$0.200 \mathrm{~m} 3 / 1994$

Implementing CSO: EM

Activity Identification Method: T05

source reduction activity: w19

OR recycling activity:

Serial Number: 30

Status:

This piece of equipment was purchased and put into service in 1994 and success is on-going.

Comments:

included above.

Significant zone reduction goals are set through the ALARA committee and often yield significant pollution prevention in site operations. 
vI. Return on Investment Accomplishment Project

Project Title: WHC, Solid Waste, Mobile Surface Contamination Monitor

Serial Number: 30

Operations Office/Site: RL/Hanford Site

Implementing CSO: EM

Site Contact: Ellen B. Dagan

(509) 376-3811/(509) 372-1926

Phone/Fax:

Project start Date $=1 /$

\section{Project Description:}

Previously, personnel manually performed radiological surveys of outdoor areas to determine the presence of contamination. Solid Waste Engineering purchased a Mobile Surface Contamination Monitor (MSCM), a tractor with an on-board radiation detection system, to mechanically perform surveys, reducing the number of personnel in radioactive areas. As well as reducing personnel exposure, approximately 220 pairs of Personal Protective Clothing were avoided in 1994, when the MSCM was first put into use. More are expected as the MSCM is used over an entire year.

Project Duration (months):

Useful Project Life (Years): 10

Performance Indicators: $\frac{\text { ROI }=[B-A]-\{[C+E] / L\} \times 100}{[C+E]}=0$

O\&M Annual Recurring Costs

(i.e. Total Annual Operating costs) (Dollars in Thousands)

Annual Costs, Before $=0.353$

Annual Costs, After $=0$

Net Annual Savings $=0.353000$
Project Funding Requirements:

(i.e. One-Time Implementation Costs) (Dollars in Thousands)

(B) Capital Investment $=$

(A) Installation Operating

Expense $=$ 
VI. Return on Investments Accomplishments

Waste/Pollutant Quantity Reduction:

Prevented Waste: (Type and amount)

Amount/Year:

Low-Level Waste (LLW)-Solid

$15.0 \mathrm{~m} 3 / 1994$

Implementing CSO: EM

Activity Identification Method: T05

source reduction activity:

OR recycling activity: $R 99$

Serial Number: 32

Status:

This procedure, implemented in 1994, is now on-going.

Comments:

included above. 
VI. Return on Investment Accomplishment Project

Project Title: WHC, Well Services, PVC Pipe Recycling

Serial Number: 32

Operations office/site: RI/Hanford Site

Implementing CSO: EM

Site Contact: Ellen B. Dagan

(509) 376-3811/(509) 372-1926

Phone/Fax:

Project start Date $=/ /$

\section{Project Description:}

Small diameter PVC pipe generated from well maintenance activities was stockpiled and considered LLW because the inside of the pipe could not be properly surveyed. working with Health Physic Technicians, well services modified procedures to allow for survey and release of the pipe. A $50 \mathrm{~cm}$ section is cut out of each 6 meter pipe and four survey swipes are conducted. If the swipes are not contaminated, then the pipe is sent to an off-site vendor for recycling.

Project Duration (months):

Useful Project Life (Years): 10

Performance Indicators: $\frac{\operatorname{ROI}=[B-A]-\{[C+E] / L\} \times 100}{[C+E]}=0$

O\&M Annual Recurring Costs

(i.e. Total Annual Operating Costs) (Dollars in Thousands)

Annual Costs, Before $=36.0$

Annual Costs, After $=0$

Net Annual Savings $=36.00000$
Project Funding Requirements:

(i.e. One-Time Implementation Costs) (Dollars in Thousands)

(B) Capital Investment =

(A) Installation Operating

Expense $=$ 
VI. Return on Investments Accomplishments

Waste/Pollutant Quantity Reduction:

Prevented Waste: (Type and amount)

Amount/Year:

Low-Ievel Wagte (ILW)-Solid

$18.0 \mathrm{~m} 3 / 1994$

Implementing cso: EM

Activity Identification Method: T05

source reduction activity:

OR recycling activity: $R 99$

Serial Number: 6

\section{Status:}

This project and its savings were completed in 1994.

included above. 
VI. Return on Investment Accomplishment Project

Project Title: ERC, 183-H Basin, Reuse of Underground Storage Tanks

Serial Number: 6

Operations Office/Site: RL/Hanford Site

Implementing CSO: EM

Site Contact: Ellen B. Dagan

(509) 376-3811/(509) 372-1926

Phone/Fax:

Project start Date $=/ /$

Project Description:

Two underground storage tanks slated for burial were reused as burial containers for additional LLW from 183-H Basin, instead of using new containers.

Project Duration (months):

Useful Project Life (Years): 1

Performance Indicators: $\frac{\operatorname{ROI}=[B-A]-\{[C+E] / L\} \times 100}{[C+E]}=0$

O\&M Annual Recurring Costs

(i.e. Total Annual Operating costs) (Dollars in Thousands)

Annual Costs, Before $=37.44$

Annual Costs, After $=0$

Net Annual Savings

$=37.44000$
Project Funding Requirements:

(i.e. One-Time Implementation Costs) (Dollars in Thousands)

(B) Capital Investment =

(A) Installation Operating Expense $=$

Total Project Funds $=(C)+(E)=0$ 


\section{Return on Investments Accomplishments}

Waste/Pollutant Quantity Reduction:

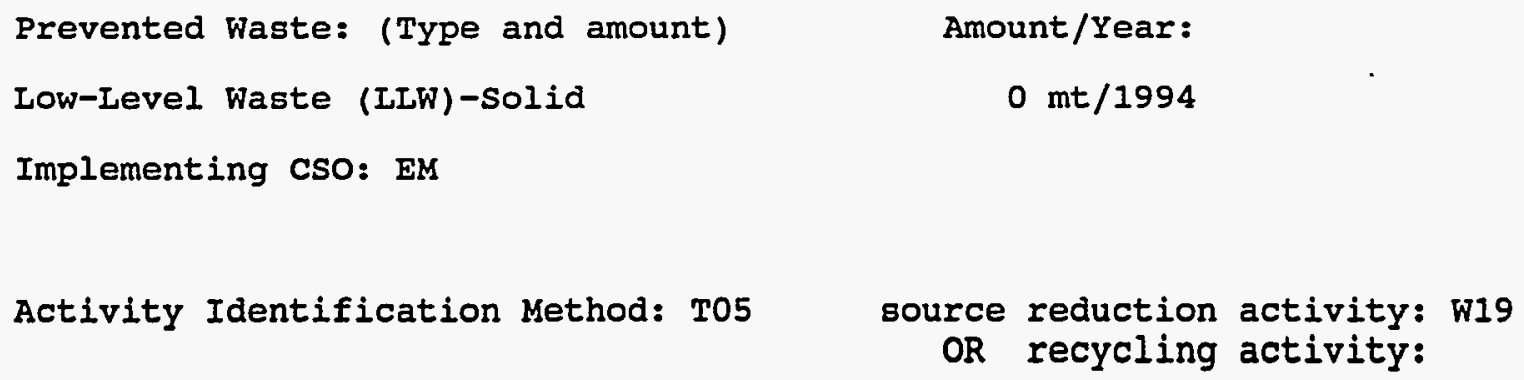

Serial Number: 8

Status:

This procedure change was instituted in 1994 and is on-going for all construction projects. 
VI. Return on Investment Accomplishment Project

Project Title: ICF KH, Project Sites, LIW soil reduction

Serial Number: 8

Operations office/Site: RL/Hanford Site

Implementing CSO: EM

Site Contact: Ellen B. Dagan

(509) 376-3811/(509) 372-1926

Phone/Fax:

Project start Date $=/ /$

Project Description:

Permission was obtained per DOE order to backfill radiologically contaminated material during construction operations. For example, if trenching is being done to install electrical lines or other construction related activities and contaminated soils are encountered, they are backfilled in the trench versus drummed and shipped to low level burial.

Project Duration (months):

Useful Project Life (Years): 10

Performance Indicators: $\frac{R O I=[B-A]-\{[C+E] / L\} \times 100}{[C+E]}=0$

O\&M Annual Recurring Costs

(i.e. Total Annual Operating Costs) (Dollars in Thousands)

Annual Costs, Before =

Annual Costs, After =

Net Annual Savings $=0$

(A)
Project Funding Requirements:

(i.e. One-Time Implementation Costs) (Dollars in Thousands)

(B) Capital Investment $=$

Installation Operating Expense $=$

Total Project Funds $=(C)+(E)=0$ 
VI. Return on Investments Accomplishments

Waste/Pollutant Quantity Reduction:

Prevented Waste: (Type and amount)

Amount/Year:

Mixed-ILW-Iiquid

$$
1.60 \mathrm{~m} 3 / 1994
$$

Implementing CSO: EM

Activity Identification Method: T05

source reduction activity: W67

OR recycling activity:

Serial Number: 21

Status:

Comments:

Included above. 
VI. Return on Investment Accomplishment Project

Project Title: WHC, 340 Facility, Tank Waste Flush Water Reduction

Serial Number: 21

Operations office/site: RL/Hanford site

Implementing CSO: EM

Site Contact: Ellen B. Dagan

(509) 376-3811/(509) 372-1926

Phone/Eax:

Project start Date $=/ /$

\section{Project Description:}

The 340 Facility installed a process water supply system in the 340 facility. This eliminated the use of a stock tank and an internal-combustion engine to provide flush water during railcar loading operations. The old system was awkward and did not provide adequate controls to meter the water used during operations. The upgrade provided on-demand pressurized water with standard control valves which optimized the amount of flush water used. It is estimated this new configuration may eliminate 400 liters of mixed waste during railcar transfers which occur every 90 days. The use of an internal combustion engine-driven pump is also eliminated. Some increase in toxicity did occur in the remaining waste stream due to the decrease of dilution.

Project Duration (months):

Useful Project Life (Years):

Performance Indicators: $\frac{R O I=[B-A]-\{[C+E] / L\} \times 100}{[C+E]}=0.00$

O\&M Annual Recurring Costs

(i.e. Total Annual Operating Costs) (Dollars in Thousands)

Annual Costs, Before =

Annual Costs, After =

Net Annual Savings $=0$
Project Funding Requirements: (i.e. One-Time Implementation Costs) (Dollars in Thousands)

(B) Capital Investment = 44

(A) Installation Operating

Expense $=0$

Total Project Funds $=(C)+(E)=44$ 
VI. Return on Investments Accomplishments

Waste/Pollutant Quantity Reduction:

Prevented Waste: (Type and amount)

Amount/Year:

Mixed-LLW-Liquid

$41.3 \mathrm{~m} 3 / 1994$

Implementing CSO: EM

Activity Identification Method: T05

source reduction activity: W64

OR recycling activity:

Serial Number: 25

Status:

Comments:

included above. 
VI. Return on Investment Accomplishment Project

Project Title: WHC, T-Plant, Prevention of precipitation waste at 2706-T

Serial Number: 25

Operations office/site: RL/Hanford site

Implementing CSO: EM

Site Contact: Ellen B. Dagan

(509) 376-3811/(509)372-1926

Phone/Fax:

Project Start Date $=1 /$

\section{Project Description:}

Precipitation was stopped from entering the 2706-T staging pad, and consequently the T-Plant mixed waste tank system. The pad was a collection point for rainwater which ran off into the pit area and was subsequently pumped to the mixed waste tank systems. A shelter was erected over the 2706-T staging pad which prevents rainwater accumulation in the pit area.

Project Duration (months):

Useful Project Life (Years): 10

Performance Indicators: $\frac{\operatorname{ROI}=[B-A]-\{[C+E] / L\} \times 100}{[C+E]}=17.50$

O\&M Annual Recurring Costs

(i.e. Total Annual Operating Costs) (Dollars in Thousands)

Annual Costs, Before $=132$

Annual Costs, After $=0$

Net Annual Savings $=132$
Project Funding Requirements:

(i.e. One-Time Implementation Costs) (Dollars in Thousands)

(B) Capital Investment $=0$

(A) Installation Operating Expense $=480$

Total Project Funds $=(C)+(E)=480$ 
vI. Return on Investments Accomplishments

Waste/Pollutant Quantity Reduction:

Prevented Waste: (Type and amount)

Amount/Year:

Mixed-ILW-Solid

$120 \mathrm{~m} 3 / 1994$

Implementing CSO: EM

Activity Identification Method: T05

source reduction activity: w19

OR recycling activity:

Serial Number: 24

Status:

Comments :

included above. 
VI. Return on Investment Accomplishment Project

Project Title: WHC, T-Plant, Treatment of Backlog Waste

Serial Number: 24

Operations office/site: RI/Hanford site

Implementing CSO: EM

Site Contact: Ellen B. Dagan

Phone/Fax:

(509) 376-3811/(509) 372-1926

Project start Date $=/ /$

\section{Project Description:}

T-Plant processed RMW (mixed waste) boxes for Tank Farms. The 33 boxes all contained some sort of anomaly, i.e., cigarette lighters, aerosol cans, mask cartridges, that prevented the waste from being classified as ILW. T-Plant operation removed the anomalies, thereby reducing the waste designation from RMW to ILW. This waste level reduction significantly reduced the cost and difficulty of managing the waste.

Project Duration (months):

Useful Project Life (Years): 1

Performance Indicators: $\frac{\operatorname{ROI}=[B-A]-\{[C+E] / L\} \times 100}{[C+E]}=0$

O\&M Annual Recurring Costs

(i.e. Total Annual Operating Costs) (Dollars in Thousands)

Annual Costs, Before $=354.82$

Annual Costs, After $=0$

Net Annual Savings $=354.8200$
Project Funding Requirements:

(i.e. One-Time Implementation Costs) (Dollars in Thousands)

(B) Capital Investment =

(A) Installation Operating Expense $=$

Total Project Funds $=(C)+(E)=0$ 


\section{Return on Investments Accomplishments}

Waste/Pollutant Quantity Reduction:

Prevented Waste: (Type and amount)

Amount/Year:

Mixed-LLW-Solid

$$
0.600 \mathrm{~m} 3 / 1994
$$

Implementing CSO: EM

Activity Identification Method: T05

source reduction activity: W19

Serial Number: 31

OR recycling activity:

Status:

Comments:

included above. 
VI. Return on Investment Accomplishment Project

Project Title: WHC, 222 S Labs, Velcro straps for Chemical Vortex Shaker

Serial Number: 31

operations office/site: RL/Hanford site

Implementing CSO: EM

Site Contact: Ellen B. Dagan

(509) 376-3811/(509) 372-1926

Phone/Fax:

Project start Date $=/ /$

\section{Project Description:}

Before samples can be subdivided for various analytical tests, they must be vortexed (stirred vigorously) for a specified amount of time to ensure homogeneity. The design of the vortex shakers does not properly accommodate the variety of glass vial sizes used in the labs, so the chemists used industrial strength green tape to hold the vials in place during the vortexing. Approximately 1.5 rolls of green tape were being used per day, which was disposed of as mixed waste after use. To eliminate this waste stream, a reusable and adjustable velcro strap was attached to the vortex shaker.

Project Duration (months):

Useful Project Life (Years): 10

Performance Indicators: $\frac{\text { ROI }=[B-A]-\{[C+E] / L\} \times 100}{[C+E]}=0$

O\&M Annual Recurring Costs

(i.e. Total Annual Operating Costs) (Dollars in Thousands)

Annual Costs, Before $=46.193$

Annual Costs, After $=0$

Net Annual Savings $=46.19300$
Project Funding Requirements:

(i.e. One-Time Implementation Costs) (Dollars in Thousands)

Capital Investment $=$

(A) Installation Operating

Expense $=$

Total Project Funds $=(C)+(E)=0$ 


\section{Return on Investments Accomplishments}

Waste/Pollutant Quantity Reduction:

Prevented Waste: (Type and amount)

Amount/Year:

RCRA-regulated-Solid

$2.50 \mathrm{mt} / 1994$

Implementing CSO: EM

Activity Identification Method: T05

source reduction activity: W42

OR recycling activity:

Serial Number: 1

Status:

Comments:

included above.

While the new product was not less costly, the substitution resulted in a reduction of toxicity. This will also result in some waste disposal cost avoidance. 


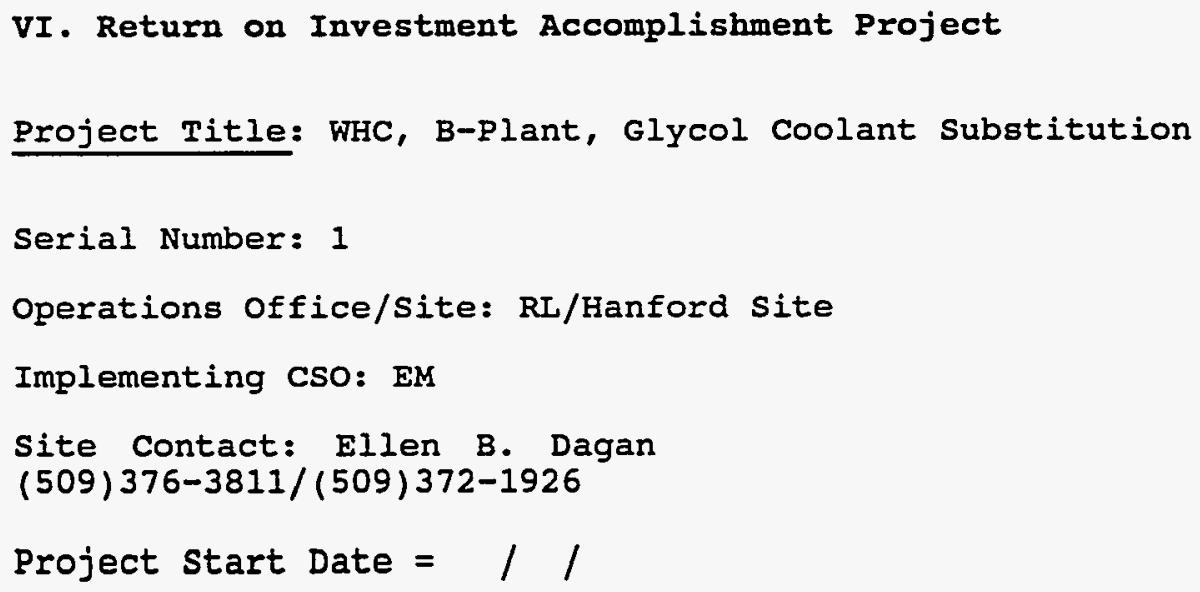

\section{Project Description:}

B-Plant purchased 2500 liters (660 gallons) of propylene glycol, a non-hazardous substitute, for use as a coolant instead of using ethylene glycol, a hazardous material. This will prevent the eventual disposal of used product as a waste.

Project Duration (months):

Useful Project Life (Years): 10

Performance Indicators: $\frac{\operatorname{ROI}=[B-A]-\{[C+E] / L\} \times 100}{[C+E]}=0$

O\&M Annual Recurring Costs

(i.e. Total Annual Operating Costs) (Dollars in Thousands)

Annual Costs, Before $=0$

Annual Costs, After $=0$

Net Annual Savings $=0$
Project Funding Requirements:

(i.e. One-Time Implementation Costs) (Dollars in Thousands)

(B) Capital Investment $=0$

(A) Installation Operating

$$
\text { Expense }=0
$$

Total Project Funds $=(C)+(E)=0$ 
VI. Return on Investments Accomplishments

Waste/Pollutant Quantity Reduction:

Prevented Waste: (Type and amount)

Amount/Year:

RCRA-regulated-solid

$2.55 \mathrm{mt} / 1994$

Implementing CSO: EM.

Activity Identification Method: T05

source reduction activity:

$O R$ recycling activity: $R 99$

Serial Number: 10

status:

Comments:

included above. 
VI. Return on Investment Accomplishment Project

Project Title: ICF KH, 1171/1226/2711E, Hydraulic Oil Recycling

Serial Number: 10

Operations office/Site: RL/Hanford Site

Implementing CSO: EM

Site Contact: Ellen B. Dagan

Phone/Fax:

(509) 376-3811/(509) 372-1926

Project start Date $=/ /$

\section{Project Description:}

When a hydraulically operated piece of equipment comes in for maintenance or repairs on the hydraulic system, Fleet operations filters and reuses the hydraulic oil if it has more than $50 \%$ of its hours of usage left. This reduces the disposal cost and new product cost.

Project Duration (months):

Useful Project Life (Years): 10

Performance Indicators: $\frac{\text { ROI }=[B-A]-\{[C+E] / L\} \times 100}{[C+E]}=328.46$

O\&M Annual Recurring Costs

(i.e. Total Annual Operating costs) (Dollars in Thousands)

Annual Costs, Before $=5.28$

Annual Costs, After $=0$

Net Annual Savings $=5.280000$
Project Funding Requirements:

(i.e. One-Time Implementation costs) (Dollars in Thousands)

(B) Capital Investment $=0$

(A) Installation Operating

$$
\text { Expense }=1.56
$$

Total Project Funds $=(C)+(E)=1.560000$ 
VI. Return on Investments Accomplishments

Waste/Pollutant Quantity Reduction:

Prevented Waste: (Type and amount)

Amount/Year:

RCRA-regulated-Solid

$0.330 \mathrm{mt} / 1994$

Implementing CSO: EM

Activity Identification Method: T05

source reduction activity: W58

OR recycling activity:

Serial Number: 17

\section{Status:}

This substitution was instituted at PFP and was implemented at Tank waste Remediation system and several Transition Project facilities. This form only reports the PFP reductions, although it it being implemented across the site.

Comments:

included above. 
VI. Return on Investment Accomplishment Project

Project Title: WHC, PFP, Reusable Alkaline Batteries

Serial Number: 17

Operations office/Site: RL/Hanford Site

Implementing CSO: EM

Site Contact: Ellen B. Dagan

Phone/Fax:

(509) $376-3811 /(509) 372-1926$

Project start Date $=/ /$

Project Description:

Plutonium Finishing Plant (PFP) replaced its one-time use alkaline batteries with rechargeable alkaline batteries. Batteries at PFP are used for pagers, flashlights, and other electronic devices. The rechargeable batteries are controlied, recharged, and reissued by facility storeroom personnel. They are recycled when they can no longer be recharged.

Project Duration (months):

Useful Project Iife (Years): 10

$\frac{\text { Performance Indicators: }}{\operatorname{ROI}=[B-A]-\{[C+E] / L\} \times 100}=177.20$

O\&M Annual Recurring costs

(i.e. Total Annual operating costs) (Dollars in Thousands)

Annual Costs, Before $=2.34$

Annual Costs, After $=0$

Net Annual Savings $=2.340000$
Project Funding Requirements:

(i.e. One-Time Implementation Costs) (Dollars in Thousands)

(B) Capital Investment $=0$

(A) Installation Operating

$$
\text { Expense }=1.25
$$

Total Project Funds $=(C)+(E)=1.250000$ 


\section{Return on Investments Accomplishments}

Waste/Pollutant Quantity Reduction:

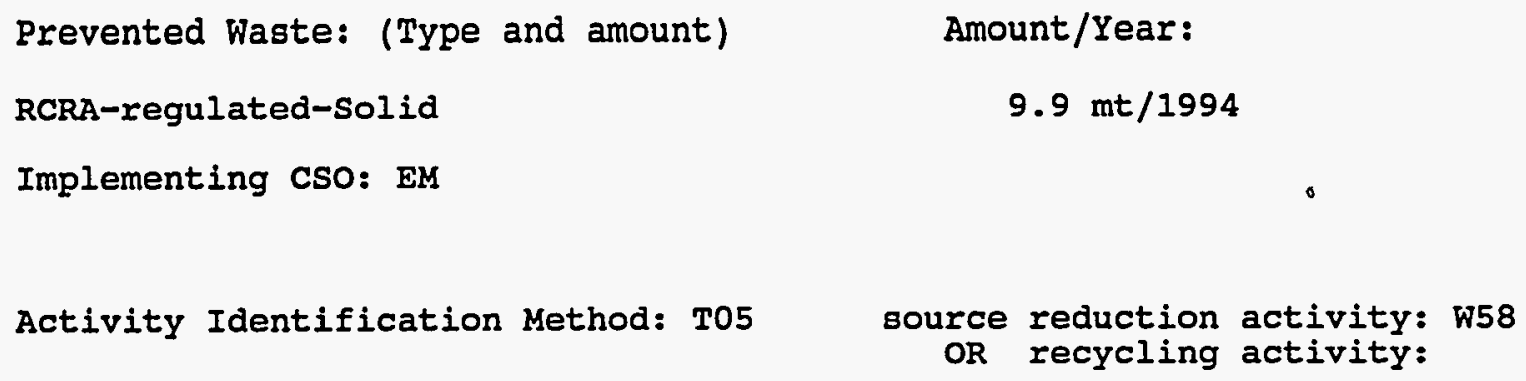

Serial Number: 27

status:

Comments:

included above. 


\section{Return on Investment Accomplishment Project \\ Project Title: WHC, N Reactor, Lead Removal from Incandescent Lightbulbs}

Serial Number: 27

Operations Office/Site: RI/Hanford site

Implementing CSO: EM

Site Contact: Ellen B. Dagan

(509) 376-3811/(509) 372-1926

Phone/Fax:

Project start Date $=/ /$

\section{Project Description:}

The $\mathrm{N}$ Reactor Maintenance personnel implemented a change in handling method for incandescent light bulbs to reduce the amount of hazardous waste requiring disposal. The bulbs are hazardous waste because they have a lead bead on the bulb end. The new handling technique involved manually removing the hazardous lead tip from each light bulb with a side-cutter wire cutters, separating the hazardous tips from the non-hazardous bulb.

Project Duration (months):

Useful Project Life (Years): 10

Performance Indicators: $\frac{\operatorname{ROI}=[\mathrm{B}-\mathrm{A}]-\{[\mathrm{C}+\mathrm{E}] / \mathrm{L}\} \times 100}{[\mathrm{C}+\mathrm{E}]}=0$

O\&M Annual Recurring Costs

(i.e. Total Annual Operating Costs) (Dollars in Thousands)

Annual Costs, Before $=18.548$

Annual Costs, After $=0$

Net Annual Savings $=18.54800$
Project Funding Requirements:

(i.e. One-Time Implementation Costs) (Dollars in Thousands)

(B) Capital Investment =

(A) Installation Operating

Expense =

Total Project Funds $=(C)+(E)=0$ 


\section{Return on Investments Accomplishments}

Waste/Pollutant Quantity Reduction:

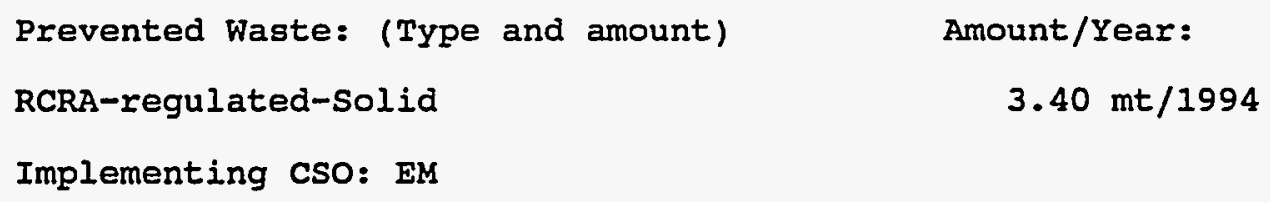

Serial Number: 28

\section{Status:}

This was implemented in 1994 and is an on-going activity.

Comments:

included above.

In addition to the RCRA waste avoidance, 70.5 cubic meters of solid sanitary waste was also avoided with this project. 


\section{Return on Investment Accomplishment Project}

Project Title: ICF KH, Custodial Services, Regulated Janitorial Products

Serial Number: 28

Operations office/Site: RL/Hanford site

Implementing CSO: EM

Site Contact: Ellen B. Dagan

(509) 376-3811/(509) 372-1926

Phone/Fax:

Project start Date $=/ /$

\section{Project Description:}

Custodial Services provides janitorial support to 334 buildings, with each building containing a janitor closet with cleaning products. Prior to this project, 168 cleaning products were used, 998 which were regulated and many of which did the same job. Through a systematic evaluation process, the following source reduction activities were implemented: aerosols were replaced with pump-type dispensers; all regulated products were replaced with non-regulated products; products were purchased in large returnable containers and used to fill smaller, reusable containers for the field use; used containers were returned to the supplier for reuse; and disposable cleaning materials (i.e., rags and buffing pads) were replaced with reusable alternatives. As a result, the number of cleaning products was reduced to 38 non-regulated items.

Project Duration (months):

Useful Project Life (Years): 10

Performance Indicators: $\frac{R O I=[B-A]-\{[C+E] / L\} \times 100}{[C+E]}=0$

O\&M Annual Recurring Costs

(i.e. Total Annual Operating Costs) (Dollars in Thousands)

Annual Costs, Before $=160.81$

Annual Costs, After $=0$

Capital Investment $=$

Installation Operating
Expense $=$

Project Funding Requirements:

(i.e. One-Time Implementation Costs) (Dollars in Thousands)

$$
\text { Expense }=
$$

Total Project Funds $=(C)+(E)=0$ 
VI. Return on Investments Accomplishments

Waste/Pollutant Quantity Reduction:

Prevented Waste: (Type and amount)

RCRA-regulated-Solid

Amount/Year:

Implementing CSO: EM

Activity Identification Method: T05 $0.040 \mathrm{mt} / 1994$

source reduction activity: W52

OR recycling activity:

Serial Number: 5

\section{Status:}

This upgrade was completed in 1994 and the savings are annual.

included above. 
VI. Return on Investment Accomplishment Project

Project Title: ERC, 105 Buildings, Electrical Upgrade

Serial Number: 5

Operations Office/site: RL/Hanford Site

Implementing cSO: EM

Site Contact: Ellen B. Dagan

Phone/Fax:

(509) 376-3811/(509) 372-1926

Project start Date $=/ /$

Project Description:

An electrical upgrade was performed on the 105-D, 105-DR, 105-F, and 105-H reactor buildings. Lights can now be turned on and off when needed instead of burning continuously. The upgrade eliminated major electrical safety hazards throughout the facilities and allows personnel safe lighted access in all areas. There are significant savings from reducing the amount of maintenance relamping required. The new lights are also more efficient and are less hazardous to dispose.

Project Duration (months):

Useful Project Life (Years): 10

Performance Indicators: $\frac{\text { ROI }=[B-A]-\{[C+E] / L\} \times 100}{[C+E]}=24.29$

O\&M Annual Recurring Costs (i.e. Total Annual Operating Costs) (Dollars in Thousands)

Annual Costs, Before $=192$

Annual Costs, After $=0$

Net Annual Savings $=192$
Project Funding Requirements:

(i.e. One-Time Implementation Costs) (Dollars in Thousands)

(B) Capital Investment $=0$

(A) Installation Operating

$$
\text { Expense }=560
$$


VI. Return on Investments Accomplishments

Waste/Pollutant Quantity Reduction:

Prevented Waste: (Type and amount)

Amount/Year:

RCRA-regulated-Solid

$0.140 \mathrm{mt} / 1994$

Implementing cSO: EM

Activity Identification Method: T05

source reduction activity: w19

OR recycling activity:

Serial Number: 7

Status:

This new procedure was implemented in 1994 and will be on-going.

Comments:

included above. 


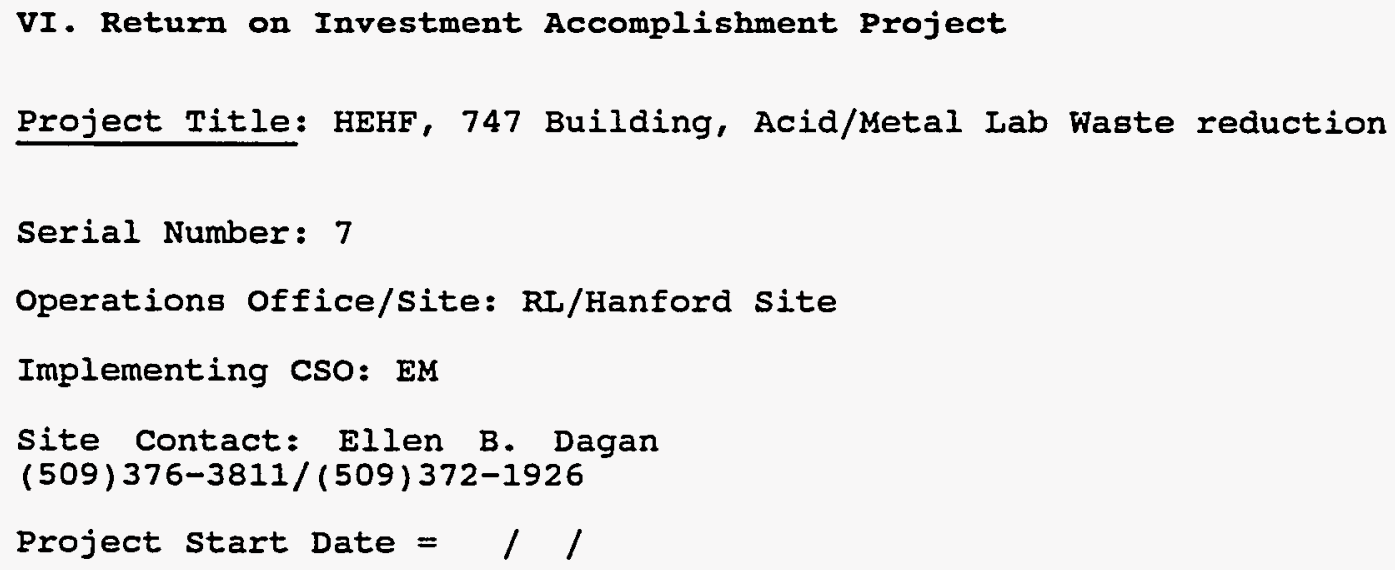

\section{Project Description:}

Analysts noticed that a large portion of most $100 \mathrm{~mL}$ acid, heavy metal standards used in the analytical laboratory were being thrown away when the expiration dates were reached (80-90 mL out of $100 \mathrm{~mL}$ discarded). Metal standards are now prepared in 10,25 , or $50 \mathrm{~mL}$ volumes, depending on the amount that will be needed. This has reduced the amount of this waste stream by approximately $50 \%$.

Project Duration (months):

Useful Project Life (Years): 10

Performance Indicators: $\frac{\operatorname{ROI}=[B-A]-\{[C+E] / L\} \times 100}{[C+E]}=0$

O\&M Annual Recurring costs

(i.e. Total Annual Operating Costs) (Dollars in Thousands)

Annual Costs, Before =

Annual Costs, After =

Net Annual Savings $=0$
Project Funding Requirements:

(i.e. One-Time Implementation costs) (Dollars in Thousands)

(B) Capital Investment =

(A) Installation Operating Expense $=$

Total Project Funds $=(C)+(E)=0$ 


\section{Return on Investments Accomplishments}

Waste/Pollutant Quantity Reduction:

Prevented Waste: (Type and amount)

Amount/Year:

RCRA-regulated-solid

$3.90 \mathrm{mt} / 1994$

Implementing cSO: EM

Activity Identification Method: T05

source reduction activity:

OR recycling activity: R19

Serial Number: 9

\section{Status:}

This activity has been on-going in the automotive shop. 
VI. Return on Investment Accomplishment Project

Project Title: ICF KH, 1171/1226/2711E, Parts Washer Solvent Recycling

Serial Number: 9

Operations Office/Site: RL/Hanford Site

Implementing CSO: EM

Site Contact: Ellen B. Dagan

(509) 376-3811/(509) 372-1926

Phone/Fax:

Project start Date $=/ /$

\section{Project Description:}

Fleet Operations filters and reuses parts washer solvent, reducing disposal costs and new product replacement costs.

Project Duration (months):

Useful Project Iife (Years): 10

$\frac{\text { Performance Indicators: }}{R O I=[B-A]-\{[C+E] / L\} \times 100}=475.85$

O\&M Annual Recurring Costs

(i.e. Total Annual Operating Costs) (Dollars in Thousands)

Annual Costs, Before $=22.738$

Annual Costs, After $=0$

(A) Installation Operating
Capital Investment $=$

0

$$
\text { Expense }=4.68
$$

Project Funding Requirements:

(i.e. One-Time Implementation Costs) (Dollars in Thousands)

Total Project Funds $=(C)+(E)=4.680000$ 
VI. Return on Investments Accomplishments

Waste/Pollutant Quantity Reduction:

Prevented Waste: (Type and amount)

Amount/Year:

Sanitary-Process Wastewater

$453 \mathrm{~m} 3 / 1994$

Implementing CSO: EM

Activity Identification Method: T05

source reduction activity:

OR recycling activity:

Serial Number: 11

status:

This is a treatment process which has disposal savings by reducing toxicity.

Comments:

included above. 


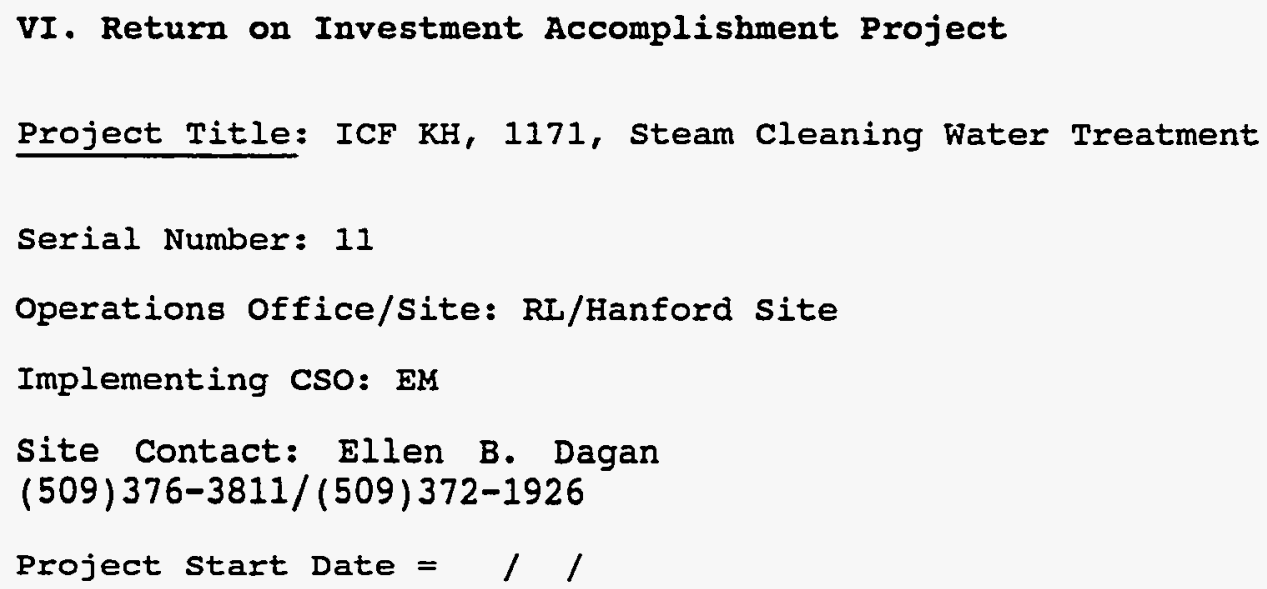

\section{Project Description:}

In the past, Fleet operations had to ship all of its steam cleaning water off-site since it could not meet the pretreatment requirements for the city of Richland. In 1994, a pretreatment filtration unit was introduced which enables the water to be discharged to the city of Richland sewer. The waste is non-regulated industrial waste water mixed with grease and oil.

Performance Indicators: $\frac{\operatorname{ROI}=[\mathrm{B}-\mathrm{A}]-[\mathrm{C}+\mathrm{E}] / \mathrm{I}\} \times 100}{[\mathrm{C}+\mathrm{E}]}=383.33$

O\&M Annual Recurring Costs

(i.e. Total Annual operating Costs) (Dollars in Thousands)

Annual Costs, Before $=150$

Annual Costs, After $=32$

Net Annual Savings $=118$
Project Funding Requirements:

(i.e. One-Time Implementation Costs) (Dollars in Thousands)

(B) Capital Investment = 30

(A) Installation Operating Expense =

Total Project Funds $=(C)+(E)=30$ 
VI. Return on Investments Accomplishments

Waste/Pollutant Quantity Reduction:

Prevented Waste: (Type and amount)

Amount/Year:

Sanitary-Process Wastewater

$175000 \mathrm{~m} 3 / 1994$

Implementing CSO: EM

Activity Identification Method: T11

source reduction activity: w51

OR recycling activity:

Serial Number: 12

status:

.

Comments:

included above.

These flow reductions were completed in order to comply with the new Treatment Effluent Disposal Facility (TEDF) design capacity. 
VI. Return on Investment Accomplishment Project

Project Title: ICF KH, 384 Powerhouse, wastewater reductions

Serial Number: 12

Operations office/Site: RL/Hanford site

Implementing cso: EM

Site Contact: Ellen B. Dagan

Phone/Fax:

(509) 376-3811/(509) 372-1926

Project start Date $=/ /$

\section{Project Description:}

Installation and operation of a closed loop cooling system at the 384 Powerhouse reduced the majority of this waste stream. The equipment it services used to receive single pass cooling, then discharged the cooling water directly to the Process sewer. Closed loop cooling reduced the need for new cooling water. some equipment and instrument replacements are also accountable for some of the waste water reduction. The waste reduced included the liquid flows of industrial waste waters consisting of boiler blowdown, equipment cooling water, and commercial water softener regeneration.

Project Duration (months):

Useful Project Life (Years): 5

Performance Indicators: $\frac{\operatorname{ROI}=[B-A]-\{[C+E] / I\} \times 100}{[C+E]}=-20.00$

O\&M Annual Recurring Costs

(i.e. Total Annual Operating costs) (Dollars in Thousands)

Annual Costs, Before $=0$

Annual Costs, After $=0$

Net Annual Savings $=0$
Project Funding Requirements:

(i.e. One-Time Implementation Costs) (Dollars in Thousands).

Capital Investment $=$

0

(C)

(A)

Installation Operating

Expense $=75$

Total Project Funds $=(C)+(E)=75$ 
VI. Return on Investments Accomplishments

Waste/Pollutant Quantity Reduction:

Prevented Waste: (Type and amount)

Amount/Year:

Sanitary-Process Wastewater

$86700 \mathrm{~m} 3 / 1994$

Implementing CSO: EM

Activity Identification Method: T05

source reduction activity: W52

OR recycling activity:

Serial Number: 19

Status:

Comments:

included above. 


\author{
VI. Return on Investment Accomplishment Project \\ Project Title: WHC, PUREX/U03, CoOling Water reduction \\ Serial Number: 19 \\ Operations office/site: RI/Hanford site \\ Implementing CSO: EM \\ Site Contact: Ellen B. Dagan \\ (509) 376-3811/(509) 372-1926 \\ Project start Date $=/ /$
}

Phone/Fax:

\title{
Project Description:
}

The thermostatic water control valves for the PUREx compressor cooling water were replaced. This reduced the cooling water flow, minimizing the total chemical sewer line flow to the 216-B3 pond by 10 percent (approximately 40 gallons per minute) in 1994.

Project Duration (months):

Useful Project Life (Years):

Performance Indicators: $\operatorname{ROI}=[B-A]-\{[C+E] / L\} \times 100=0$ $[\mathrm{C}+\mathrm{E}]$

O\&M Annual Recurring Costs

(i.e. Total Annual Operating Costs) (Dollars in Thousands)

Project Funding Requirements: (i.e. One-Time Implementation Costs) (Dollars in Thousands)

Annual Costs, Before =

Annual Costs, After =

Net Annual Savings $=0$
(B) Capital Investment =

(A) Installation Operating Expense =

Total Project Funds $=(C)+(E)=0$ 
VI. Return on Investments Accomplishments

Waste/Pollutant Quantity Reduction:

Prevented Waste: (Type and amount)

Amount/Year:

Sanitary-Process Wastewater

$3410 \mathrm{~m} 3 / 1994$

Implementing CSO: EM

Activity Identification Method: T05

source reduction activity: w19

OR recycling activity:

Serial Number: 26

Status:

This waste reduction is on-going.

Comments:

included above. 
VI. Return on Investment Accomplishment Project

Project Title: WHC, T-Plant, Eliminating Effluent Discharge to Ditch

Serial Number: 26

Operations office/Site: RL/Hanford Site

Implementing cso: $\mathrm{EM}$

Site Contact: Ellen B. Dagan

(509) 376-3811/(509) 372-1926

Phone/Fax:

Project start Date $=/ /$

Project Description:

Using water to cool the pressurized waste reactor (PWR) fuel pool was ceased in 1994. After sampling the PWR pool for several weeks, it was determined that the temperature of the pool had stabilized and an increase in radioactivity would not occur. Thus, no more cooling water was required. This waste minimization activity avoids approximately 1 million gallons of effluent discharged to the ditch per year.

Project Duration (months):

Useful Project Life (Years): 10

Performance Indicators: $\frac{\operatorname{ROI}=[B-A]-\{[C+E] / L\} \times 100}{[C+E]}=0$

O\&M Annual Recurring Costs

(i.e. Total Annual Operating costs) (Dollars in Thousands)

Annual Costs, Before =

Annual Costs, After =

Net Annual Savings $=0$
Project Funding Requirements:

(i.e. One-Time Implementation costs) (Dollars in Thousands)

(B) Capital Investment $=$

(A) Installation Operating Expense $=$

Total Project Funds $=(C)+(E)=0$ 
VI. Return on Investments Accomplishments

Waste/Pollutant Quantity Reduction:

Prevented Waste: (Type and amount)

Amount/Year:

Sanitary-solid

$0.205 \mathrm{mt} / 1994$

Implementing CSO: EM

Activity Identification Method: T05

source reduction activity: $\$ 53$

OR recycling activity:

Serial Number: 15

Status:

This was a one-time activity that may be used in future similar waste disposal situations.

comments:

included above. 
VI. Return on Investment Accomplishment Project

Project Title: WHC, PFP, Absorption of Expired Anti-foaming Agent

Serial Number: 15

Operations office/site: RL/Hanford site

Implementing CSO: EM

Site Contact: Ellen B. Dagan

(509) 376-3811/(509) 372-1926

Phone/Fax:

Project start Date $=/ /$

\section{Project Description:}

Diatomaceous earth or kitty litter has frequently been used to absorb free liquids in waste drums, greatly increasing the volume of the waste stream. An alternative absorbent was used to absorb a 55 gallon drum of an expired anti-foaming agent, previously designated as a non-regulated waste. The alternative absorbent was able to absorb the full drum of anti-foaming agent in its original container with only a 0.28 displacement ratio.

Project Duration (months):

Useful Project Life (Years): 1

Performance Indicators: $\frac{\operatorname{ROI}=[\mathrm{B}-\mathrm{A}]-\{[\mathrm{C}+\mathrm{E}] / \mathrm{L}\} \times 100}{[\mathrm{C}+\mathrm{E}]}=650.00$

O\&M Annual Recurring Costs

(i.e. Total Annual Operating Costs) (Dollars in Thousands)

Annual Costs, Before $=0.75$

Annual Costs, After $=0$

Net Annual Savings $=0.750000$
Project Funding Requirements:

(i.e. One-Time Implementation costs) (Dollars in Thousands)

(B) Capital Investment $=0$

(A) Installation Operating Expense $=0.1$

Total Project Funds $=(C)+(E)=0.100000$ 


\section{Return on Investments Accomplishments}

Waste/Pollutant Quantity Reduction:

Prevented Waste: (Type and amount)

Amount/Year:

Sanitary-solid

$1.52 \mathrm{mt} / 1994$

Implementing CSO: EM

Activity Identification Method: T05

source reduction activity:

OR recycling activity: $\mathrm{R} 99$

Serial Number: 34

Status:

Comments :

included above. 


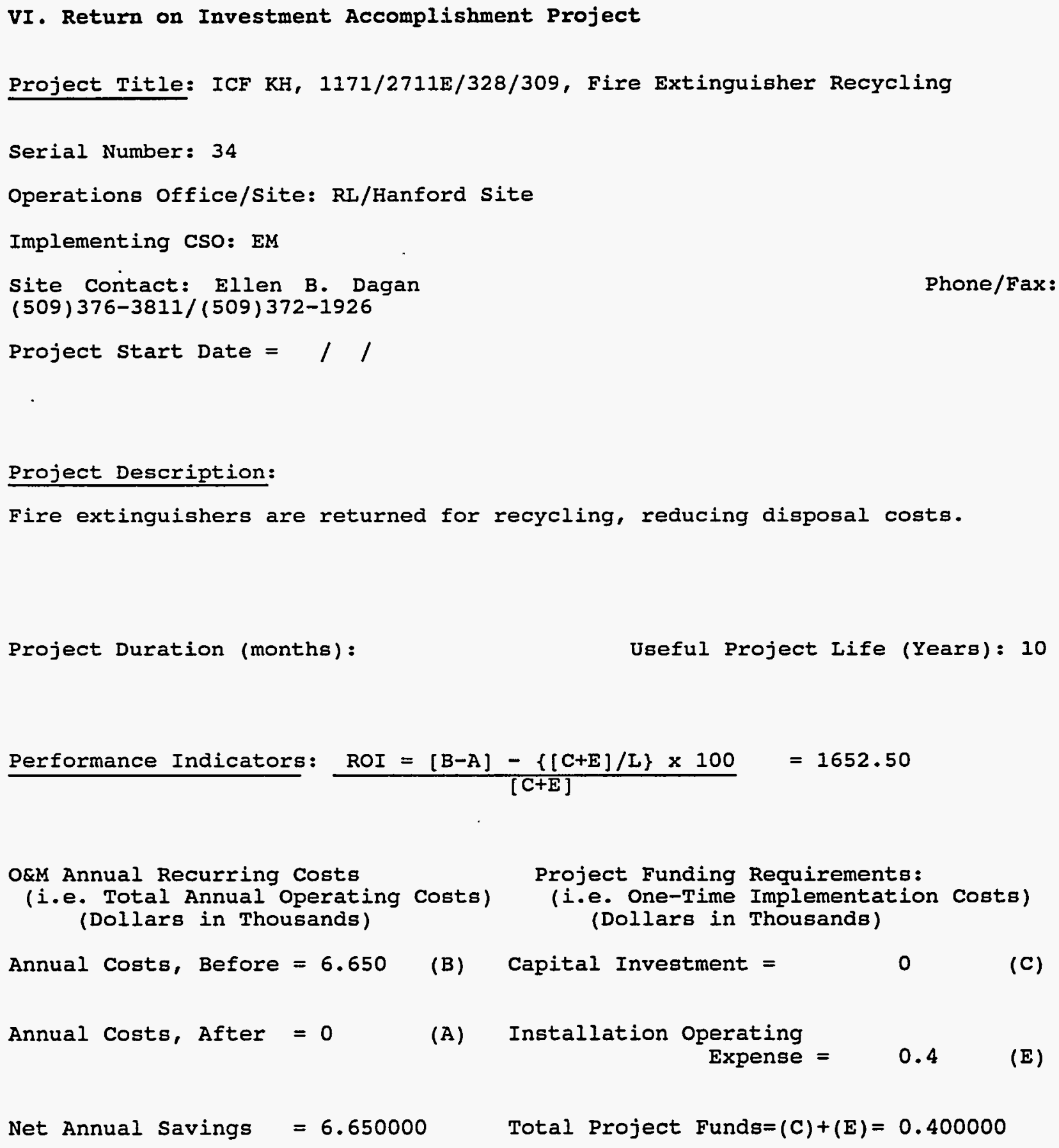




\section{Return on Investments Accomplishments}

Waste/Pollutant Quantity Reduction:

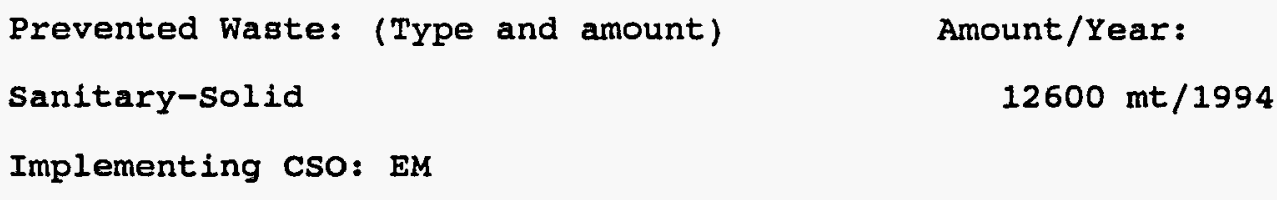

Activity Identification Method: T05

source reduction activity:

OR recycling activity: $R 99$

Serial Number: 4

\section{status:}

Project was complete with the D\&D of 190-B, a building on-site. These recycling methods are and will be used in similar activities.

\section{Comments:}

Included above. 
VI. Return on Investment Accomplishment Project

Project Title: ERC, 190-B, Building Debris

Serial Number: 4

Operations office/site: RL/Hanford site

Implementing CSO: $\mathrm{EM}$

Site Contact: Ellen B. Dagan

(509) 376-3811/(509) 372-1926

Phone/Fax:

Project start Date $=/ /$

\section{Project Description:}

Building debris (concrete and recyclable metals) from the demolition of 190-B was segregated and recycled. Concrete was crushed and used for road construction material. The metals were sold as scrap to a vendor.

Project Duration (months):

Useful Project Life (Years): 1

Performance Indicators: $\operatorname{ROI}=[\mathrm{B}-\mathrm{A}]-\{[\mathrm{C}+\mathrm{E}] / \mathrm{L}\} \times 100=0$

O\&M Annual Recurring Costs

(1.e. Total Annual Operating Costs) (Dollars in Thousands)

Annual Costs, Before $=90$

Annual Costs, After $=0$

Net Annual Savings $=90$
Project Funding Requirements:

(i.e. One-Time Implementation Costs) (Dollars in Thousands)

(B) Capital Investment =

(A) Installation Operating Expense =

Total Project Funds $=(C)+(E)=0$ 
VI. Return on Investments Accomplishments

Waste/Pollutant Quantity Reduction:

Prevented Waste: (TYpe and amount)

Amount/Year:

state-regulated-solid

$4.46 \mathrm{mt} / 1994$

Implementing CSO: EM

Activity Identification Method: T05

source reduction activity:

OR recycling activity: $R 99$

Serial Number: 33

Status:

Comments :

Included above. 
VI. Return on Investment Accomplishment Project

Project Title: ICF KH, 1171/1226/2711E, Automotive Antifreeze Recycling

Serial Number: 33

Operations office/site: RL/Hanford site

Implementing CSO: EM

Site Contact: Ellen B. Dagan

(509) 376-3811/(509) 372-1926

Phone/Fax:

Project start Date $=/ /$

\section{Project Description:}

Used antifreeze was recycled on-site to reduce disposal cost and new product replacement cost.

Project Duration (months):

Useful Project Life (Years): 10

Performance Indicators: $\frac{R O I=[B-A]-\{[C+E] / L\} \times 100}{[C+E]}=0$

O\&M Annual Recurring Costs

(i.e. Total Annual Operating Costs) (Dollars in Thousands)

Project Funding Requirements:

(i.e. One-Time Implementation Costs) (Dollars in Thousands)

Annual Costs, Before $=19.019$

(B) Capital Investment =

Annual Costs, After $=2.4160$

(A) Installation Operating Expense $=$

Net Annual savings $=16.603000$ Total Project Funds $=(C)+(E)=0$ 


\section{Return on Investments Accomplishments}

Waste/Pollutant Quantity Reduction:

'Prevented Waste: (Type and amount)

Amount/Year:

TSCA-regulated-solid

$14.8 \mathrm{mt} / 1994$

Implementing CSO: EM

Activity Identification Method: T05

source reduction activity:

OR recycling activity:

Serial Number: 13

Status:

Comments:

included above.

This is treatment in order to reclassify PCB-contaminated transformers, resulting in a volume reduction. 
VI. Return on Investment Accomplishment Project

Project Title: ICF KH, Electrical Utilities, Reclassifying PCB oil/equip.

Serial Number: 13

Operations office/site: RL/Hanford site

Implementing CSO: EM

Site Contact: Ellen B. Dagan

(509) 376-3811/(509) 372-1926

Phone/Fax:

Project start Date $=/ /$

\section{Project Description:}

Retrofilling activity was performed on 10 regulated $\mathrm{PCB}-\mathrm{contaminated}$ transformers to reclassify them as non-PCB. By retrofiling the transformers, and successfully reclassifying them, only the disposal of the oil and the rinsate is regulated. Retrofilling activities include: (1) Draining and flushing the transformer; (2) Returning the transformer to service; (3) Reclassification of transformer once all time, temperature, sampling, and record keeping criteria have been met. Succesgful completion of these actions reclassified the transformers as non-regulated by Federal (40 CFR 761) and state (WAC-173-303) standards.

Project Duration (months):

Useful Project Life (Years): 1

Performance Indicators: $\frac{R O I=[B-A]-\{[C+E] / L\} \times 100}{[C+E]}=0$

O\&M Annual Recurring Costs

(i.e. Total Annual Operating Costs) (Dollars in Thousands)

Annual Costs, Before $=$

Annual Costs, After =

(B)

(A)

Installation Operating

Expense $=$

Project Funding Requirements:

(i.e. One-Time Implementation Costs) (Dollars in Thousands)

Capital Investment $=$

)

Net Annual Savings $=0$

Total Project Funds $=(C)+(E)=0$ 
VI. Return on Investments Accomplishments

Waste/Pollutant Quantity Reduction:

Prevented Waste: (Type and amount)

Transuranic Waste (TRU)-Liquid

Implementing CSO: EM

Activity Identification Method: T05

Serial Number: 16
Amount/Year:

$1150 \mathrm{~m} 3 / 1994$ source reduction activity: W58

OR recycling activity:

status:

This change was done during the planning phase of a clean up project, eliminating future waste. The change in the planned process occurred in 1994.

Comments:

Included above. 
VI. Return on Investment Accomplishment Project

Project Title: WHC, PFP, Waste Tank Volume Reduction

Serial Number: 16

Operations office/site: RL/Hanford site

Implementing CSO: EM

Site Contact: Ellen B. Dagan

(509) 376-3811/(509) 372-1926

Phone/Fax:

Project start Date $=/ /$

\section{Project Description:}

The original plan, through operation of the Plutonium Reclamation Facility (PRF) and the Remote Mechanical C-Line (RMC), it was calculated that 300,000 gallons of waste would be generated and transferred to Tank Farms for storage. Instead of using the solvent Extraction system at the Plutonium Finishing Plant (PFP), sludge stabilization Processing has been initiated using the scrap stabilization furnaces in Hood $21 \mathrm{C}$. This will allow most reactive scrap to be treated in a manner which eliminates wet chemistry wastes by $100 \%$ and dry glovebox waste by at least 508. Processing of the remaining plutonium containing material is expected to be accomplished using glovebox scale processes with greatly reduced waste generation. The final waste volume has not been determined, but could be 250,000 gallons.

Project Duration (months):

Useful Project Life (Yearg):

Performance Indicators: $\frac{\operatorname{ROI}=[B-A]-\{[C+E] / L\} \times 100}{[C+E]}=0$

O\&M Annual Recurring costs

(i.e. Total Annual Operating Costs) (Dollars in Thousands)

Annual Costs, Before =

Annual Costs, After =

(A)

Net Annual Savings $=0$

Hanford site

Project Funding Requirements:

(i.e. One-Time Implementation Costs) (Dollars in Thousands)

Capital Investment $=$

Installation Operating Expense =

Total Project Funds $=(C)+(E)=0$ 
VI. Return on Investments Accomplishments

Waste/Pollutant Quantity Reduction:

Prevented Waste: (Type and amount)

Amount/Year:

Transuranic Waste (TRU)-Solid

$2.10 \mathrm{~m} 3 / 1994$

Implementing cSO: EM

Activity Identification Method: T05

source reduction activity: w19

OR recycling activity:

Serial Number: 18

status:

Comments:

Included above. 
VI. Return on Investment Accomplishment Project

Project Title: WHC, PFP, X-Ray Technology for FL-10 Containers

Serial Number: 18

Operations office/site: RL/Hanford site

Implementing CSO: EM

Site Contact: Ellen B. Dagan

Phone/Fax:

(509) 376-3811/(509) 372-1926

Project start Date $=/ /$

Project Description:

Historically, Plutonium Finishing Plant (PFP) personnel would open each FL-10 container and check the inner container for vessel integrity (vessels contain highly corrosive hydrochloric and hydrofluoric acids). Instead, it was suggested to use NDE X-ray technology to examine the internal integrity of the vessel. This process eliminates several types of TRU contaminated wastes, such as: greenhouses, plastic, personal protective equipment, masks, tools, and rags used for decontamination. This process also reduces radiological risks to associated personnel performing the tasks and possible contamination spread.

Project Duration (months):

Useful Project Life (Years): 10

Performance Indicatorg: $\frac{R O I=[B-A]-\{[C+E] / L\} \times 100}{[C+E]}=219.40$

O\&M Annual Recurring Costs

(i.e. Total Annual Operating Costs) (Dollars in Thousands)

Annual Costs, Before $=22.94$

Annual Costs, After $=0$

Net Annual Savings

$=22.94000$
Project Funding Requirements: (i.e. One-Time Implementation Costg) (Dollars in Thousands)

(B) Capital Investment =

0

Installation operating Expense 10

Total Project Funds $=(C)+(E)=10$ 


\section{VII. cso specific Information}

CSO: EM

Summary statement of Operational status and its affect on Waste Generation.

The Hanford site has a complete environmental restoration mission, its focus being to shut down and decommission the reactors and site facilities, as well as clean up the 1,450 square kilometers of land. In 1994, the activitieg contributing to Hanford's environmental restoration mission continued to accelerate. This increase included characterization, decontamination and decommisgioning (D\&D), analytical services, and transition projects, resulting in a waste increase despite the significant $P 2$ successes on site. Specific activities resulting in higher waste generation included increasing the rate of transition and cleanout of facilities, a greater number of D\&D of buildings on site, and increasing laboratory activity. The labs, some of the larger waste generators on-site, are expecting requests for analytical services to increase as restoration activities proceed.

Table 4.0 cso: EM Waste Generation.

\begin{tabular}{|c|c|c|c|c|}
\hline Waste Type & Routine & $\begin{array}{c}\text { Non } \\
\text { Routine }\end{array}$ & Total & $\begin{array}{l}\text { Process } \\
\text { Wastewaters }\end{array}$ \\
\hline High Ievel Waste & $\begin{array}{ll}0 & \mathrm{~m} 3 \\
0 & \mathrm{~m} 3\end{array}$ & $\begin{array}{ll}0 & \mathrm{~m} 3 \\
0 & \mathrm{~m} 3\end{array}$ & $\begin{array}{ll}0 & \mathrm{~m} 3 \\
0 & \mathrm{~m} 3\end{array}$ & $0 \mathrm{~m} 3$ \\
\hline Transuranic Waste (TRU) $($ (S) & $\begin{array}{rl}0 & \mathrm{~m} 3 \\
195 & \mathrm{~m} 3\end{array}$ & $\begin{array}{ll}0 & \mathrm{~m} 3 \\
0 & \mathrm{~m} 3\end{array}$ & $\begin{array}{r}0 \\
1953 \\
\mathrm{~m} 3\end{array}$ & $0 \mathrm{~m} 3$ \\
\hline Mixed-TRU & $\begin{array}{r}0 \mathrm{m3} \\
102 \mathrm{~m} 3\end{array}$ & $\begin{array}{ll}0 & \mathrm{~m} 3 \\
0 & \mathrm{~m} 3\end{array}$ & $\begin{array}{rr}0 & \mathrm{~m} 3 \\
102 & \mathrm{~m} 3\end{array}$ & $0=3$ \\
\hline $\begin{array}{ll} & \text { (I) } \\
\text { Low-Level Waste (LLW) } & \text { (S) }\end{array}$ & $\begin{array}{r}0 \mathrm{~m} 3 \\
3900 \mathrm{~m} 3\end{array}$ & $\begin{array}{r}0 \mathrm{~m} 3 \\
218 \mathrm{~m} 3\end{array}$ & $\begin{array}{r}0 \mathrm{~m} 3 \\
4120 \mathrm{~m} 3\end{array}$ & $0 \mathrm{~m} 3$ \\
\hline Mixed-IIW & $\begin{array}{rl}2500 & \mathrm{~m} 3 \\
570 & \mathrm{~m} 3\end{array}$ & $\begin{array}{rr}0 & \mathrm{~m} 3 \\
1740 & \mathrm{~m} 3\end{array}$ & $\begin{array}{l}2500 \mathrm{~m} 3 \\
2310 \mathrm{~m} 3\end{array}$ & $0 \mathrm{~m} 3$ \\
\hline RCRA Regulated & $70.9 \mathrm{mt}$ & $285 \mathrm{mt}$ & $356 \mathrm{mt}$ & $0 \mathrm{~m} 3$ \\
\hline state Regulated & $138 \mathrm{mt}$ & $47.6 \mathrm{mt}$ & $186 \mathrm{mt}$ & $0 \mathrm{~m} 3$ \\
\hline TSCA Regulated & 0 mt & $85.5 \mathrm{mt}$ & $85.5 \mathrm{mt}$ & $0 \mathrm{~m} 3$ \\
\hline Mixed-TSCA & $0 \mathrm{mt}$ & $0.590 \mathrm{mt}$ & $0.590 \mathrm{mt}$ & $0 \mathrm{~m} 3$ \\
\hline
\end{tabular}




\section{Summary of Information from site Waste Minimization and Pollution Prevention (WMIN/PP) Awareness Plan}

The following information is based on the May 1994 update to the site-wide waste Minimization and Pollution Prevention Awareness Plan. All information has been taken directly from the plan (the appropriate sections are listed in brackets [] refer to the Plan suggested Outline contained in guidance issued by Deputy Secretary White on March 28, 1994).

\section{Site-wide Quantitative Goals for Newly Generated Wastes*} [Section IV. Goals]

\begin{tabular}{|c|c|c|c|c|c|c|c|c|c|c|c|c|c|c|c|c|}
\hline \multirow{2}{*}{$\begin{array}{l}\text { Waste Type } \\
\text { ELW }\end{array}$} & \multicolumn{2}{|c|}{1993} & \multicolumn{2}{|c|}{1994} & \multicolumn{2}{|c|}{1995} & \multicolumn{2}{|c|}{1996} & \multicolumn{2}{|c|}{1997} & \multicolumn{2}{|c|}{1998} & \multicolumn{2}{|c|}{1999} & \multicolumn{2}{|l|}{2000} \\
\hline & 0 & m3 & 0 & $\mathrm{~m} 3$ & 0 & $\mathrm{~m} 3$ & 0 & m3 & 0 & m3 & 0 & $\mathrm{~m} 3$ & 0 & $\mathrm{~m} 3$ & 0 & m3 \\
\hline LLW & 3390 & m3 & -730.000 & m3 & 125 & m3 & 125 & $\mathrm{~m} 3$ & 125 & m3 & 125 & m3 & 125 & m3 & 0 & m3 \\
\hline TRU & 271 & m3 & 76.0 & $\mathrm{~m} 3$ & 13.1 & m3 & 13.1 & m3 & 13.1 & m3 & 13.1 & $\mathrm{~m} 3$ & 13.1 & m3 & 0 & m3 \\
\hline Mixed-TRU & 97.9 & m3 & -4.100 & $\mathbf{m} 3$ & 0.540 & $\mathbf{m} 3$ & 0.540 & $\mathbf{m} 3$ & 0.540 & m3 & 0.540 & m3 & 0.540 & $\mathbf{m} 3$ & 0 & $\mathrm{~m} 3$ \\
\hline Mixed-LLW & 5260 & $\mathrm{~m} 3$ & 452 & m3 & 110 & m3 & 18.0 & m3 & 18.0 & m3 & 18.0 & $\mathbf{m} 3$ & 18.0 & m3 & 0 & $\mathrm{~m} 3$ \\
\hline Mixed-TSCA & 8.20 & m3 & 7.60 & $\mathrm{~m} 3$ & 0 & $\mathbf{m} 3$ & 0 & m3 & 0 & m3 & 0 & $\mathrm{~m} 3$ & 0 & m3 3 & 0 & m3 \\
\hline RCRA Reg ** & 378 & mt & 0 & mt & 2.56 & mt & 2.56 & mt & 2.56 & mt & 2.56 & mt & 2.56 & mt & 0 & mot \\
\hline State Reg ** & 72.8 & mt & 0.000 & mt & 1.09 & mt & 0.728 & mt & 0.728 & mt & 0.728 & mt & 0.728 & mt & 0 & mt \\
\hline TSCA Reg ** & 139 & mot & 0 & mt & 0 & $\mathrm{mt}$ & 0 & mt & 0 & mt & 0 & mt & 0 & mt & 0 & $\mathrm{mt}$ \\
\hline Sanitary ** & 7660 & mt & -1500 & mt & 0 & mt & 0 & $\mathrm{mt}$ & 0 & mt & 0 & ast & 0 & mt & 0 & $\mathrm{mt}$ \\
\hline
\end{tabular}

II: Narrative on Qualitative Goals for Resotration and D\&D Activities. [Section IV. Goals - see Table 1]

Qualitative goals have been set for Restoration and D\&D activities. The ER/D\&D goal for the Hanford site is to establish best management practices for all significant material streams, in order to minimize waste and prevent pollution to the extent that is technically and economically feasible.

*/ Newly Generated Waste = Routine, ongoing production operations and research and development.

**/ Separate source reduction and recycling goals have been included. 
Summary of Information from Site Waste Minimization and Pollution Prevention (WMIN/PP) Awareness Plan

III. Pollution Prevention Opportunity Assessment coals:

[Section IV. Goals - see Table 1]

$\begin{array}{rll}\text { Completed as of the end of CY 1994: } & 6 \\ \text { Number planned for CY 1995: } & 106 \\ \text { Number planned for CY 1996: } & 64 \\ \text { Number planned for CY 1997: } & 66 \\ \text { Number planned for CY 1998: } & 66 \\ \text { Number planned for CY 1999: } & 69 \\ \text { Number planned for CY 2000: } & \text { NA }\end{array}$

IV. WMin/PP Program Budget for site: (by Fiscal Year)

[Section V. - WMin/PP Activities and Resource Requirements]

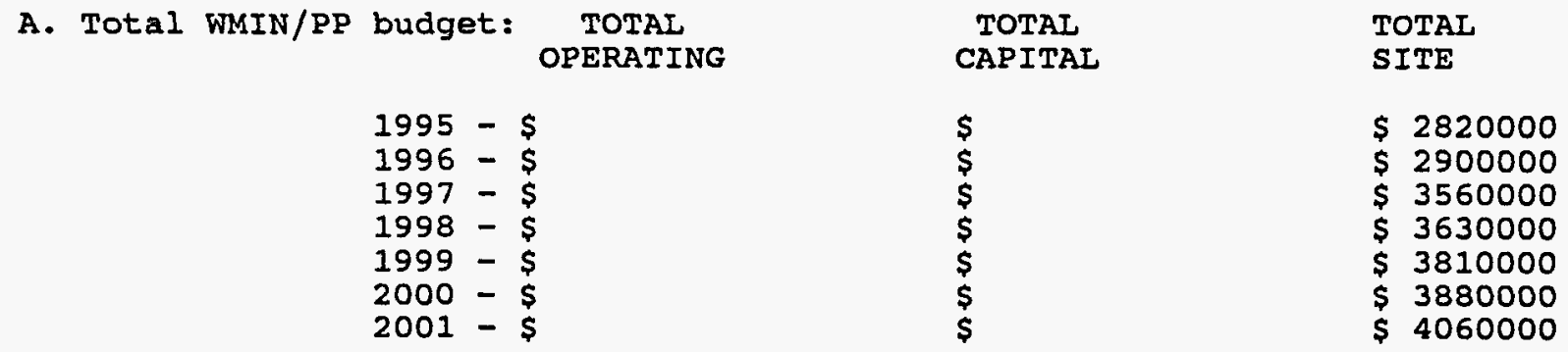

[Section V. - see Table 2, item 5]

$\begin{array}{lll}\text { B. Total Budget for PPOAs: } & 1995-\$ 700000 & 1999-\$ \text { Unknown } \\ & 1996-\$ \text { Unknown } & 2000-\$ \text { Unknown } \\ 1997-\$ \text { Unknown } & 2001-\$ \text { Unknown } \\ 1998-\$ \text { Unknown } & \end{array}$

Site-wide Resources (\$) Needed for Key Programmatic Elements:

C. Implement Source Reduction Opportunitieg for:

$$
\text { FY } 1995
$$

1996

Unknown

Unknown

1997 1998

Unknown

Radio $\$$ Unknown

Mixed \$ Unknown

\section{Unknown}

Unknown

Unknown

Unknown

Unt

1999

Unknown

Unknown

Unknown

D. Implement Recycling Opportunities for: FY 1995

Hazar \$ Unknown

Radio $\$$ Unknown

Mixed $\$$ Unknown $\begin{array}{ll}1996 & 1997 \\ \text { Unknown } & \text { Unknown } \\ \text { Unknown } & \text { Unknown }\end{array}$

Unknown Unknown

$$
1998
$$

Unknown

Unknown

Unknown

$$
1999
$$

Unknown

Unknown

Unknown
2000

Unknown

Unknown

Unknown

2000

Unknown

Unknown

Unknown
2001

Unknown

Unknown

Unknown

2001

Unknown

Unknown

Unknown

E. Implement Source Reduction and Recycling Opportunities for Sanitary Wastestreams

$\begin{array}{rllllll}\text { FY } 1995 & 1996 & 1997 & 1998 & 1999 & 2000 & 2001 \\ \text { \$ Unknown } & \text { Unknown } & \text { Unknown } & \text { Unknown } & \text { Unknown } & \text { Unknown } & \text { Unknown }\end{array}$




\section{Summary of Information from site Waste Minimization and Pollution Prevention (WMIN/PP) Awareness Plan}

\section{v. Narrative on Overall Program status/Evaluation: [Section VII. Program Status - see Table 2, item 9]}

Strengths of the Hanford site program have led to many WMin/P2 accomplishments during 1994. Many of these accomplishments have been identified and implemented with limited resources. This can be credited to gignificant grasgroots efforts at the facility employee level with the support of the central P2 Groups of Westinghouse Hanford Company and ICF Kaiser Hanford. These accomplishments are described in detail in other sections of the report. Additionally, funds from DOE-HQ EM-334 significantly helped improve implementation and attitude towards WMin/P2.

During 1994, central P2 groups at the Hanford site increased in pergonnel and workscope, their level of technical facility support increased, and they completed development of key tools and began implementation of these tools. overall, the site is moving from tool development to a focus on implementation of P2 tools and opportunities. During 1994, the introduction of the Pollution Prevention Opportunity Assessment (PPOA) method to the facilities promises to be a significant contributor to the development and implementation of $\mathrm{P} 2$ initiatives in 1995. Goals for completing PPOAs set in January 1995 and the requirement of PPOAs as documentation of a P2 program will encourage facilities to participate. An emphasis on return on investment analysis when conducting PPOAs will promote implementation. In addition to PPOAs, a goal setting methodology was developed which sets goals for all waste types at the generator level and aggregates them for the site. Finally, P2 awareness and training programs have been strong.

Areas of improvement include: maintaining support of $p 2$ during staff reductions at all levels; streamlining reporting through electronic media; and more independent funding for pollution prevention programs. The Hanford site plans to address these issue in 1995.

VI. Optional Reduction Goals for Process Wastewater: [Section IV. Goals - see Table 1]

$\begin{array}{llcc}\text { Waste Type } & 1993 & 1994 & 1995 \\ \text { Radioactive } & 0 & \mathrm{~m} 3 & \mathrm{x} \\ \text { Mixed } & 0 & \mathrm{~m} 3 & \chi \\ \text { Hazardous } & 0 & \mathrm{~m} 3 & \chi \\ \text { Sanitary } & 0 & \mathrm{~m} 3 & \chi\end{array}$

$\begin{array}{rrr}995 & 1996 & 1997 \\ x & x & \\ z & z & \\ x & z & x\end{array}$

997
$z$
$z$
$x$

$\begin{array}{rr}998 & 1999 \\ x & x \\ x & x \\ x & x\end{array}$

$\begin{array}{ll}x & x \\ x & x \\ x & x\end{array}$

